\title{
Nüzulün Asırlık Serencamı: Arızîlikten Daimiliğe, Aynîlikten Nakdiliğe (17. Yüzyılda Malatya Sancağı Özelinde) ${ }^{1}$
}

\author{
Hasan ARSLAN \\ Dr. Öğr. Üyesi, Kahramanmaraş Sütçü İmam Üniversitesi, \\ Fen Edebiyat Fakültesi, Tarih Bölümü \\ hasanarslan1@gmail.com \\ Orcid ID: https://orcid.org/0000-0002-7945-6689
}

\begin{abstract}
Öz
Malatya, kesin olarak Yavuz Sultan Selim tarafindan gönderilen Hadım Sinan Paşa eliyle 28 Temmuz 1516 tarihinde Osmanlı Devleti'ne ilhak edildi. Kısa süreli olarak Arap ve Rum/Rum-1 Hadis eyaletlerine bağlı bir sancak olarak teşkilatlandırılmışsa da 16. yüzyılın ikinci yarısından 19. yüzyıla kadar Dulkadir/Maraş eyaletine bağlı bir sancak olarak idare edilmiştir. Araştırılan devrede Maraş eyaletine bağlı olan Malatya sancağ 1 , vergi çevresi olarak Malatya, Kâhta, Şure, Taşabad, Behisni, Gerger ve Hısn-1 Mansur-SamsadBezeki kazalarından oluşmaktaydı. Nüzul vergisi, Osmanlı hükûmetinin külliyetli seferler esnasında askerin zahire ve mühimmatını karşılamak için ihdas ve istimal ettiği bir usuldü. Osmanlı vergi tasnifinde Avarız-1 Divaniye veya tekâlif-i örfiye grubuna dâhildi. En az 16. yüzyılın başlarından itibaren olağanüstü hallerde savaş ihtiyaçlarına karşılık arpa ve un/buğday üzerinden aynen alınırdı. Daha sonra malî, askerî ve ekonomik zaruretlerden dolayı hem süreklilik kazanmış, hem de nakdileşmiştir. Bu tetkikte kaynak olarak, T.C. Cumhurbaşkanlığı Devlet Arşivleri Başkanlığı bünyesindeki Osmanlı Arşivi’nin çeşitli fonlarında kayıtlı onlarca İcmal Avarız ve Mevkufat Defterleri başta olarak çok sayıda arşiv belgesi kullanılmıştır. Kaynakların elverdiği ölçüde Malatya kazalarında nüzulün tarh-teslim süreçlerinin işleyişi, tahakkukundaki muvaffakiyet ve bu devredeki serencamı yani değişimi/dönüşümü izlenmiştir. Ayrıca vergi mükelleflerinin bu süreçteki keyfiyeti ve ortaya çıkan taşra-merkez ilişkileri irdelenmiştir. Bu araştırma, dönemin ve bölgenin mali/iktisadi ve içtimai hatta idari vaziyetini biraz daha aydınlatmıştır.
\end{abstract}

Anahtar Kelimeler: Nüzul, Bedel-i nüzul, Osmanlı Devleti, Malatya Sancağı, Avarız-1 Divaniye, Avarızhane/Nüzulhane.

\footnotetext{
${ }^{1}$ Makale Geliş/Kabul Tarihi: 03.06.2021 / 06.09.2021

Künye Bilgisi: Arslan, H. (2021). Nüzulün asırlık serencamı: arızîlikten daimiliğe, aynîlikten nakdiliğe (17. yüzyılda Malatya sancağı özelinde). Kahramanmaraş Sütçü Imam Üniversitesi Sosyal Bilimler Dergisi, 18 (3), 1797-1834. DOI: 10.33437/ksusbd.947504
} 


\title{
Centuries-old Serencam of Nüzül: From Incidental to Constant, From in Kind to Cash (In the Case of Malatya Sanjak in the 17th Century)
}

\begin{abstract}
Malatya was annexed to the Ottoman Empire on 28 July 1516 by the hand of Hadim Sinan Pasha, who was sent by Yavuz Sultan Selim. Although it was organized as a sanjak affiliated to Arab and Rum/Rum-1 Hadis provinces for a short time, it was administered as a sanjak affiliated to Dulkadir/Maraş province from the second half of the 16th century to the 19th century. In the researched period, Malatya sanjak consisted of Malatya, Kâhta, Şure, Taşabad, Behisni, Gerger and Hisn-1 Mansur-Samsad-Bezeki kazas (jurisdictions) as tax circles and was included in the provinces of Maras. Nüzül levy was a method created and used by the Ottoman government in order to meet the military's provisions and ammunition by implementing massive campaigns. It was included in the Awaridi Diwaniyya wa Takâlif-i urfiyya group in the Ottoman tax classification. From at least the beginning of the 16th century, in extraordinary situations, it was bought in kind on barley and flour / wheat for war expenses. Later, it gained continuity and became cash due to financial, military and economic necessities. A large number of archival documents were used as a source in this study, especially the tens of Icmal Avariz and Mevkufat Notebooks, which were registered in various funds of the Ottoman Archive under the Presidency of the State Archives of the Republic of Turkey. To the extent that the resources allow, the functioning of the assessment-delivery processes of the nüzül in Malatya kazas districts), the success in its accrual and its change/transformation in this period have been observed. In addition, the circumstance of taxpayers in this process and the emerging provincial-central relations were examined. This research has manifested the financial/economic, social and even administrative situation of the period and the region a little more.
\end{abstract}

Keywords: Nuzul, badal-i nuzul, Ottoman State, Malatya Sanjak, Awarid-i Diwaniyya wa Takâlif-i urfiyya, Awaridkhane/Nuzulkhane.

\section{GİRIŞ}

Malatya, kesin olarak Yavuz Sultan Selim tarafindan gönderilen Hadım Sinan Paşa eliyle 28 Temmuz 1516 tarihinde Osmanlı ülkesine ilhak edilmiştir. Sancak haline getirilen Malatya, önceleri Arap eyaletine bağlanmışsa da 1522 y1lında Rum eyaletine dâhil edilmiştir. 16. yüzyılın ilk yarısında doğuya yapılan seferler dolayısıyla zaman zaman Dulkadir/Maraş eyaletine bağlanmış fakat Rum 
eyaletine bağgl1lı̆g 1568 y1lına kadar sürmüştür. Maraş eyaletine sürekli bağlanması bu tarihten itibaren başlamış ve kesintisiz bir biçimde 19. yüzyıla kadar devam etmiştir (İlknur, 2002: 46-9; Özlü, 2015: 76; Toprak, 2015: 21-22). Araştırmaya esas dönemde Maraş eyaletine bağlı olan Malatya sancağı, vergi çevresi olarak Malatya, Kâhta, Şure, Taşabad, Behisni, Gerger ve Hısn-1 MansurSamsad-Bezeki kazalarından oluşuyordu.

Daha çok Devlet Arşivleri Başkanlığına bağlı Osmanlı Arşivi’ndeki avarızhane ve mevkufat defterlerinde kayıtlı bilgilerin kullanıldı̆̆ 1 bu çalışmanın amacı, Osmanlı Devleti'nin bir dönüm/dönüşüm ve değişim devri olan 17. yüzyılda, Malatya sancağı halkına yüklediği nüzul vergisini sistematik bir şekilde incelemektir. Bu sayede Sancak içerisindeki avarızhane/nüzulhane sayılarındaki değişim; nüzulün tarh sıklığı ve miktarı ile zaman içerisinde yükümlülüğün mahiyetinde meydana gelen değişim takip edilerek değerlendirilecektir. Ayrıca vergiye muhatap olan reayanın bu zaman dilimindeki durumları, ağırlaşan ve sıklaşan nüzul karşısındaki tepkisi, onunla baş etme çabaları, sesini duyurabilme gayretleri ve bütün bu tepkilere Merkezi hükûmet ve Sultanın verdiği cevapların da imkânlar ölçüsünde üzerinde durulacaktır. Bu araştırma, incelenen bölgenin o zamanki sosyo-ekonomik durumu ile ilgili bilgilere yenilerini katacaktır.

\section{YÜZYILDA MALATYA SANCAĞINDA NÜZULÜN SERENCAMI}

Sözlüklerde "bir yere inme, konma" manalarına gelen nüzul, askerî ve mali terim olarak ise: bir askerî kıtanın beslenmesi için cins ve miktarı önceden belirlenmiş zahirenin temin edilerek emredilen yerlerde veya stratejik noktalarda inşa edilen ambarlara götürülerek indirilmesi ve hazır bulundurulması anlamında kullanılmıştır (Güçer, 1964: 69; İşbilir, 2007: 111).

Yapılan yeni çalışmalarla nüzul yükümlülüğünün, en az 15. yüzyılın sonlarından beri Osmanlı mali-askeri sistemi içinde mevcut olduğu ve 16 . yüzyılın başlarından itibaren de hemen hemen her seferde sistemli olarak talep ve tahsil edildiği ortaya konulmuştur (Polat, 2018: 831-41). Sefere çıkan asker için gerekli buğday/un ile ordudaki hayvanlar için arpadan ibaret aynî veya nakdî bedel olarak toplanan gerçek bir vergi hüviyetindeki bu teklif, Osmanlı vergi sisteminde avarız-1 divaniye/tekâlif-i örfiye/tekâlif-i şâkka grubunda yer almaktaydı. Bu tür mükellefiyetler ise Tanzimat'ın ilânına kadar olağanüstü hallerde ve özellikle savaş ihtiyaçlarını karşılamak üzere, hükümdarın emri ile halkın doğrudan doğruya devlete vermek zorunda tutulduğu her türlü hizmet, eşya veya para şeklindeki yükümlülükleri kapsamaktaydı (Barkan, 1993: 13).

Osmanlı Devleti, seferberlik dönemlerinde hareket halindeki ordularının zahire ve mühimmat ihtiyacını karşılamak için sistemli ve girift bir lojistik düzen kurmuştu. Sefer sırasında askerî birliklerin ihtiyacı olan erzak ile orduda kullandığ 1 hayvanlara yem olarak arpa, saman ve taze ot ile yakacak olarak 
kullanılan odunun temininde nüzul, iştira ve sürsat denilen üç farklı usul kullanmaktaydı (İnalcık, 2017: 113; İnalcık, 1980: 314). Devlet bu usullerden nüzul sayesinde reaya üzerine dolaysız vergiler salarak bir miktar zahireyi ordu için temin etmelerini şart koşuyordu (KK.d., 2775: 3; Barkan, 1993: 14).

Nüzul vergisi, avarız akçesine benzer bir biçimde, kadılar marifetiyle kazaya tabi yerleşim birimlerindeki vergi mükellefi hane veya mücerretlerden teşekkül ettirilen avarızhane daha doğrusu nüzulhane üzerinden tarh, tevzi ve tahsil edilmekteydi. Araştırmaya esas dönemin arifesinde avarızhane/nüzulhane sisteminde önemli bir değişim ve dönüşüm meydana geldiği anlaşllıyor. Nitekim avarızhane tabiri, 15. ve 16. yüzyıllarda gerçek hane veya vergi mükellefi yetişkin erkek (nefer) tabiri ile eşanlamlı olarak kullanılırken, 16. yüzyılın sonlarından itibaren "birden fazla gerçek hane veya vergi veren mücerretten müteşekkil bir vergi birimi" olarak mahiyet değişikliğine uğramıştır (Çakar, 2006: 3; Emecen, 1989: 123-24). Bu dönüşümle eş zamanlı olarak uzun süren seferler dolayısıyla ordunun artan mühimmat ve hazinenin nakit ihtiyacının karşılanabilmesi için mümkün olduğunca muafiyetlerin kapsamı daraltılırken vergi yükümlülügünde "emlâk ve arazi sahibi" olma esas ölçü olarak belirlenmiştir (Güçer, 1964: 71; Darling, 1996: 157-179). Osmanlı ülkesindeki tüm vergi mükellefleri, Müslimgayrimüslim ayırımı yapılmaksızın (Selçuk, 2008: 164) adli-idari bir ünite olan kazalar esas alınarak avarızhane tahrirlerine tabi tutulur ve oradaki vergiye dâhil olan tüm kişiler kaydedilirdi. Bulundukları şehir, kasaba ve köylerdeki demografik durum ile kendilerinin ekonomik güçlerine, zaman ve vaziyetin icabına göre bu mükelleflerden 3-10 tanesi hatta bazen 20-30 tanesinden itibari bir vergi ünitesi olan avarızhane/nüzulhaneler oluşturulmaktaydı (Barkan, 1993: 14; Güçer, 1964: 70-73). Mali durumu yetersiz olanlar, çalışamayanlar, kimsesizler, özürlüler, çocuklar, askerîler ve belli bazı hizmetleri ifa eden halk grupları nüzul vergisinden muaf tutulmuşlardır (Cezar, 1965: 25)². Kısaca belgelerin ifadesiyle bir kimse avarızhanesine kaydedilmişse nüzul ve benzeri tekâlif-i örfìye muhatap olurdu (MAD.d., 3260: 74). Bu yüzden avarızhanesine dâhil reayadan bazıları, bu tür yükümlülüklerden kaçmak için bazen hileli yollara başvururdu. Mesela, 1630'lu yıllarda Malatya kasabasında bazı uyanık kimseler böyle bir yola girmişlerdi. Bunlar, "Menzil beygirleri çekiyoruz." diye nüzulden

\footnotetext{
${ }^{2}$ Askerîye ve ilmîye sınıf mensupları, çeşitli idari hizmetleri ifa edenler; yuvacı, kayacı, çadırcı, derbentçi, köprücü, çeltikçi, menzilci gibi bazı sınıflar; kereste, zift, yelken bezi, ok, yay, saray mutfağı için çeşitli yiyecek, yeniçeri çuhası gibi aynî mükellefiyetleri olanlar; ayrıca serhat bölgelerinde bulunanlar; vakıf reayası; körlük, delilik, düşkünlük gibi bedenî sakatlıkları olan kimseler avarızdan muaf tutulmuşlardır. Muafiyet meselesi hakkında detaylı bilgi için ayrıca bkz. Barkan, 1993: 14-16; Özel, 2000: 37-38; Sahillioğlu, 1991: 108. Malatya Sancağında avarızdan muaf tutulan bazı kimselerin kimlik, meslek ve hizmetleri için bkz. Vakıf ve Mülk Defteri, 2007: 146, 260, 294.
} 
muaf olan mahallelere gidip yerleşince eski mahallelerindeki mükellefler perişan olmuşlardı. Bunun önüne geçmek için Revan seferi esnasında geçtiği yerlerde halkın şikâyetlerini dinleyip sorunlarını çözen IV. Murad, bu tür kimselere ayırım yapılmaması ve bunların hem menzil ile ilgili vazifelerini hem de eskiden olduğu gibi tekâlif-i örfiyelerini birlikte yerine getirmeleri yönünde 23 Aralık 1634 tarihinde ferman çıkarmıştır (D.MKF.d., 27445: 63-64). Yine Gerger ve Kâhta kazalarında 300 kadar nefer, "Kâhta Kalesine kul yazılmışı." diyerek muafnameleri olmadığı halde avarız akçelerini üç sene boyunca ödemeyince durumdan zarar gören kaza ahalisi mahkemeye gelerek durumu şikâyet etmişlerdir. Ahali, eğer adı geçenler bu tarzda kendileriyle beraber vergilerini vermezlerse herkesin perişan ve perakende olacağını belirttikten sonra hallerinin olduğu gibi payitahta bildirilmesini kadıya rica edince o da durumu İstanbul'a iletmiştir. Merkezi hükûmetin cevabı nettir: adı geçenler avarızhanesine dâhillerse vergilerini vermeleri gerektiğine dair zikredilen kazaların kadılarına hitaben 1611 ilkbaharında hüküm gönderilmiştir (MAD.d., 3260: 74). 9 Nisan 1611 tarihinde Hısn-1 Mansur-Samsad-Bezeki kazasında tımar sahiplerinin yaptıkları gibi bazı devlet memurları da reayadan bir kısmını kendi evlerine/çiftliklerine alarak onları bu tür vergileri ödemekten kaçırıyorlardı. $\mathrm{Bu}$ konuyu ilgililere bildiren kadının arzına göre yine başka kadılıklardan gelip kendi kazalarında yerleşenler de başka bahaneler ileri sürerek avarız türü vergilerini yerine getirmekte ayak diretiyorlardı. Bunlar için de idarenin cevabı aynıydı: bulundukları topraklardaki reaya ile birlikte tahammüllerine göre bu tür tekâlife iştirak edeceklerdi (MAD.d., 3260: 74).

Malatya liva/kazasının araştırmaya esas döneme ait mufassal avarızhane tahrir defterleri günümüze gelmediğinden livada bir avarızhanenin kaç gerçek hane veya vergiye tabi mücerretten teşekkül ettiğini tespit etmek zorlaşmıştır. Ancak Mayıs 1623 tarihinde, Malatya'nın da yer aldığ Zülkadriye eyaleti muhafazasında olan Vezir Yusuf Paşa ve bu eyaletteki kadılara yazılan bir ferman içeriğinden buradaki kazalarda bir avarızhanenin üç vergi mükellefinden oluşturulduğu anlaşılmaktadır. Bu fermanda öncelikle Dulkadir eyaletindeki sancakların avarızhanelerinin uzun zamandan beri bozuk ve düzensiz olduğu, bu durumun avarız toplayan memurların işlerini zorlaştırdığı vurgulanmıştır. Kadılara, İstanbul'dan gönderilen görevli marifetiyle tek tek yoklamaları yapılan vergi mükelleflerinden üç tanesinin bir avarızhanesi sayılarak yeniden tashih ve tanzim edilmesi, avarızhanelerin defter haline getirilmesi, bundan sonraki işlemlerde bu defterlere göre hareket edilmesi ve bu yeni defterlerin bir suretlerinin de merkeze gönderilmesi emredilmiştir (AŞS, 170A: 293-94).

Şüphesiz seferlerdeki askerlerin savaşma gücünün devamı ancak gerekli olan zad ü zahire (yiyecek, azık) ile mühimmatın zamanında ve noksansız tahsil edilmesine, ordunun gelişinden evvel belirlenen yere veya savaş sahasına nakledilmesine bağlıdır (A.DVNSMHM.d., 3: 70). Dolayısıyla nüzul ve benzeri 
tekâlif, seferlerde ordunun kaderini belirleyici bir role sahipti (İnbaşı, 2004, 219220). Bu öneminden ötürü merkezi hükûmet, sefer kararı aldıktan sonra hemen hazırlıklara başlardı. Bu kapsamda ülkedeki ilgili tüm ümeraya sefer hazırlık emirleri gönderirdi. Gerek sefer için gerekse de başka sebepten dolayı ihtiyaç duyduğu nakit veya mühimmatın yekûnunu tespit ettikten sonra bunu memleketin umum avarızhanesi adedine taksim ederdi. Maliye'nin Mevkufat Kalemi tarafından Hazine-i Âmire'de korunan Mevkufat defterlerinden çıkarılan nişanlı ve mühürlü suretler ile konuya ilişkin Divan-1 hümayun ve Maliye tarafından yazılan emirler, bu iş için tayin edilen mübaşirler varsa onlar ile birlikte aksi durumda ise doğrudan her mıntıkanın kadısına gönderilirdi. Onlara yetki alanlarındaki avarızhanelerine göre hesaplanmış miktarlarda aynî nüzulün veya nakdi bedelinin herhangi bir gecikmeye mahal vermeden toplanmasını emrederdi (C.ML. 378-15521; Mc Gowan, 1981: 1329). Bahsedilen emirlere muhatap olan Malatya livasındaki kadılar da diğer meslektaşları gibi derhal harekete geçerlerdi. Kendi kaza halkına yüklenilen, cins ve miktarı zikredilen defter suretlerinde belirtilen bu bedeli, şehir merkezinde vilayet ileri gelenleri ve mahallelerin itimada şayan kimseleri veya temsilcileri huzuruyla, kırsal alanda ise köy imamı ve kethüdası marifetiyle avarıza dâhil tüm mükelleflere tahammüllerine göre yani maddi imkânları ölçüsünde adalet üzere dağıtıllardı (A.DVNSMHM.d., 96: 66; Barkan, 1993: 15).

Nüzül zahiresinin toplanması, çuvallanıp belirlenen menzillere götürülerek Ordu Nüzül Emini'ne ${ }^{3}$ ya da mirî zahire ambarlarına teslim edilmesi gibi işler, zaman zaman merkezden görevlendirilen mübaşirler tarafından yürütülse de, genellikle kadıların uhdelerine verilen bir vazifeydi (İşbilir, 2002: 151; D.MKF. d., 27423: 51-52). Her kadı, kendi kazasından ihraç ettiği hububatı, reayanın temin ettiği veya ücretini ödediği kiralık mekkari (yük) hayvanlarına yükleyip kervanın başına da bizzat kendisi geçerek hükûmetin belirlediği yere naklederdi. Zahireyi burada nüzul eminine veya ambar eminine teslim ederlerdi (A.DVNSMHM.d., 59:41; D.MKF.d., 27445: 156-57; Güçer, 1964: 78-80)4 . Mesela, Malatya kazası naibi Molla Ali Halife, 1580 yılı için kendi kazası ahalisinden istenen toplam 2.277 kile (1.708 kilesi arpa, 569 kilesi un olan) zahirenin tahsil edebildiği 1.809 kilesini (1.514 kile arpa ve 295 kile un) götürüp ordu birliklerine teslim etmiştir (KK.d., 2553: 12-14). Ayn1 minval üzere, 1027/1617 y1lı Malatya nüzulü için mübaşir tayin edilen Hasan Bey ve kaza kadıları, istenilen 1.562 kile arpa ve unun tamamını 19 Ekim 1618 tarihinde nüzul emini Mehmed Efendi'ye teslim etmişlerdi (D.MKF.d., 27423: 52).

\footnotetext{
${ }^{3}$ Nüzül Emini: Sefere çıkan ordunun konaklayacağı yerleri ve oralarda yiyecek ve içecekleri hazırlayan memur hakkında kullanılan bir tabirdir (Pakalın, 1983: 710).

${ }^{4}$ Başka kaynaklar için bkz. A.DVNSMHM.d., 44: 154; A.DVNSMHM.d., 53: 281; A.DVNSMHM.d., 32: 311; A.DVNSMHM.d., 59: 13.
} 
Kadılar, ordudaki defterdar gözetiminde, nüzul zahiresini teslim ettiğine dair mühürlü bir temessük yani bir teslim tutanağı alırlardı. Aldıkları bu temessük mucibince Maliyenin Mevkufat kaleminde hane hesabı üzerinden muhasebesini gördürürlerdi. Akabinde bu işle artık alakalarının kalmadığını ve bu hizmetlerinin tamamladığını gösteren nişanlı yani tuğralı ve mühürlü bir temessükü buradan da alınca işlem tamamlanırdı (AE.SIBR 1-42; TS.MA.e. 551/94 (TSMA No: 2834/1); KK.d., 2576: 10, 22; D.MKF.d., 27445:156-157) ${ }^{5}$. Nüzulü aynen çıkarma ve emredilen yere nakletme mecburiyetinde olan kadıların, taşıma külfetinden kurtulmak veya başka bir bölgede daha ucuza hububat almak maksadıyla kendi kazalarında ahaliden akçe tahsil etmeleri de şiddetle men edilmişti (A.DVNSMHM.d., 53: 281). Fakat yüzyılın başlarındaki emirlerde zahirenin istenilen mahalden çıkarılması sıkı sıkıya tembih edilirken dönemin sonlarında artık istenirse mahallinde nakden toplanarak hububatın ve zahirenin bol olduğu savaş alanı ve sefer güzergâhına daha yakın yerlerden satın alınarak tedarik edilmesi salık verilmekteydi. Bu ikinci hareket tarzının, zaman, emniyet ve külfet açısından devletin daha çok işine geldiği 12 Kasım 1697 tarihli bir hüküm münderecatından anlaşılmaktadır (MAD.d., 3471: 1).

Tüm bu izahlardan açıkça anlaşıldığ üzere nüzulün kazaları dâhilinde tevzi edilmesi, tahsili, muhafazası ve istenilen yere ulaştırılması ile ilgili başlıca yetki ve sorumluluk Malatya sancağındaki kadı/naiplere verilmişti. Bunlara Merkezi idareden gönderilen hüküm ve fermanlarda ilk başta nüzul/nüzul bedellerinin toplanmasının sefere gidecek askerlerin zahire ve mühimmatı için nedenli elzem ve ehemmiyetli olduğu ifade edilirdi. Kendilerinden bu iş için görevlendirilen mübaşirin elindeki emr-i şerif ile mühürlü ve nişanlı mevkûfât defteri sureti mûcebince toplanması gereken nüzul/bedel-i nüzullerin herhangi bir ihmale mahal vermeden, bir an evvel tahsil edilerek gönderilmesi şiddetle emredilirdi. Ayrıca, onların voyvoda, evkaf mütevellileri, kethüdayerleri ve yeniçerilerle kendi aralarında işbirliği yaparak bedel-i nüzul akçelerinin reayadan zulüm ve taaddi etmeden toplamaları ve bu konunun ihmal edilmemesi gönderilen bütün emirnamelerde 1srarla tekrarlanırd1 (MŞS, 1: 151, 168, 171; A.DVNSMHM.d., 44: 154).

Tüm bu işlerin ayan-1 vilayet ile reaya huzurunda hak ve adalet üzere yapılması sıkı sıkıya tembih edilirken onların bu konuda hassasiyet göstermeleri, zulüm ve teaddiden uzak durmaları aksi takdirde görevden alınıp sürülecekleri belirtilerek tehdit edilirlerdi ${ }^{6}$. Mesela, 10 Nisan 1611 tarihli ve Malatya sancağına

\footnotetext{
${ }^{5}$ Nüzül vergisinin tarh, tevzi ve tahsili hakkında geniş malumat için bkz. Güçer, 1964: 70-92; İnbaş1, 2004: 220.

${ }^{6}$ Divan'dan yerel kadı ve diğer yetkililere gönderilen ve tüm bu uyarı ve unsurları içeren birkaç hüküm için bkz. A.DVNSMHM.d., 53: 281; A.DVNSMHM.d., 44: 154; KK. d., 2576: 10; AŞS, 21: 63; TS.MA.d., 10642: 1.
} 
tabi Behisni kadısına irsal edilen bir hükümde 1018/1609-10 senesine mahsuben toplanıp Behisni kalesinde muhafaza edilen 400 kuruş ile kazada daha başka ne miktar nüzul ve sürsat akçesi varsa eksiksiz tahsil edilip muaccelen ordu hazinesine gönderilmesi hususunda kendisi ikaz ve tembihlenmiştir (MAD.d., 3260: 84). Netice itibariyle kadı/naipler, kendi bölgelerinde kazaî vazifelerinin yanı sıra oranın iktisadi hayatını düzenlenmekte, mıntıkasındaki halktan talep edilen nüzul, sürsat, iştira ve diğer tekâlif-i örfiyenin tevzi ve tahsilinde geniş vazife ve salahiyetlere sahip fakat mesuliyeti de o ölçüde ağır bir mali temsilci durumundaydılar. Başlıca sorumluluk livadaki kadılarda olmakla beraber başta Malatya sancak beyi ve şehirdeki diğer yetkililere de nüzulün toplanması konusunda kadıya yardımcı olmaları, bu işi organize ve denetlemeleri konusunda emirler gönderilmekteydi. Bu emirlerde adı geçenler bu hususta sıkı bir şekilde ikaz edilmiş, hatta ihmalleri durumunda mansıp ve dirliklerinin alındıktan başka gereği gibi cezalandırılacakları vurgulanarak tehdit edilmişlerdir (A.DVNSMHM.d., 59: 13; A.DVNSMHM.d., 32: 311).

Aynî olarak tarh, tevzi ve tahsil edilen nüzul zahiresi, sefere çıkan başta yeniçeri ve altı bölük halkı olmak üzere sair kapı kullarının erzakları için sarf edilirdi. Sefer hazırlıkları kapsamında nüzul ile ilgili sadır olan ve yetkililere gönderilen tüm emirlerde asker için hayati önem taşıyan zahirenin tedarik edilip emredilen yere nakledilerek hazır edilmesinin, devletin önemli ve lazım işlerinden yani "umur-1 lazıme", "umur-1 ehem" veya "ehemm-i mühimmat”tan olduğu daima vurgulanmıştır (A.DVNSMHM.d., 59: 41; KK.d., 2576: 10). Ancak Devlet tarafindan çok önem verilen ve seferlerde ordunun kaderinde belirleyici bir rol oynayan bu tür yükümlülüklerin halk tarafindan zaman zaman önemsenmediği veya görevlilerce ihmal edildiği de bir vakıadır. Örneğin, şark seferinde olan Osman Paşa'nın Zülkadriye Vilayetinden istediği nüzul, bennak ve ırgat akçelerinin zamanında orduya gelmediği belirtilerek bu iş için görevlendirilen Divan çavuşlarından Cafer marifetiyle en kısa sürede eksiksiz bir şekilde tahsil edildikten sonra, acele olarak götürülüp serdara teslim edilmesi için eyaletteki kadılara emr-i şerifler gönderilmiştir (A.DVNSMHM.d., 55: 203) ${ }^{7}$. Başka ve ilginç bir süreç de 1585 yılında yaşanmıştır. Osmanlı Merkezi Hükûmeti, bu tarihlerde gerçekleşen Tebriz seferi için Malatya kazası halkından aynî olarak istediği nüzulü, kadının kazalarında kıtlık ve pahalılığın olduğunu bildirmesi üzerine, önce nakde çevirmiş ve her haneden 2 flori avarız alınmasını emretmiştir. Ancak daha sonra sefer için nüzulün kritik bir ehemmiyet arz etmesi üzerine bu kararından vazgeçerek toplanacak aynî nüzulün dörtte birinin un ve gerisi arpa olmak üzere her 30 haneden bir müd ${ }^{8}$ zahire ihraç ederek mahall-i

\footnotetext{
${ }^{7}$ Bu konuda başka örnekler için bkz. A.DVNSMHM.d., 32: 285, 311, 343-44; A.DVNS MHM.d., 63: 27, 34.

${ }^{8} 1$ müd, 20 İstanbul kilesine eşittir. İstanbul kilesi ile 1 kile arpa 22,25 kg. idi (Hinz, 1990: 51).
} 
memure iletmeleri mevzuunda Malatya kadısına hüküm gönderilmiştir (A.DVNSMHM.d., 59: 41).

Kural olarak aynî bir yükümlülük olup sefer halindeki ordunun mühimmat/ zahiresi için başvurulan nüzul vergisi, sefer güzergâhına yakın yerlerden aynî olarak, uzak olan yerlerden ise nakden toplanıyordu. Devlet, umumiyetle, seferleri Rumeli tarafına gerçekleştirirse bu yöndeki kazalardan nüzul yükümlülüklerini aynî olarak yerine getirmesini talep ederken, Anadolu tarafındakilerden ise bunun nakdi karşılığını, mekkari (kiralık nakliye hayvanı) bedeli mantığ sefer düzenlenecekse de tam tersi gerçekleşirdi (MAD.d., 3471: 1; KK.d., 2624: 84-85).

İncelemeye esas dönemde Malatya Sancağında nüzul vergisi, aynen alındığı gibi nakden de tarh ve tahsil edilmiştir. Mesela, isyan halinde bulunan Erzurum valisi Abaza Mehmed Paşa'nın tenkili maksadıyla veziriazam Hüsrev Paşa'nın 1037/1627-28 tarihinde düzenlediği sefer sırasında, askerî harekât sahasının dışında kalan Malatya'nın bağlı olduğu Zülkadriye ile birlikte Karaman, Diyarbekir, Haleb ve Şam eyaletlerinde nüzul, bedel olarak tahsil edilmiştir (MAD.d., 6634: 21-22). Nüzulün aynî olarak alındığı zamanlarda Malatya kazası avarızhane/nüzulhane sayıları ve bunlardan talep edilen hububat ve unun miktarı aşağıdaki tablodaki gibi idi:

Tablo 1. 17. Yüzyılda Malatya Kazası/Livasından Aynen Talep Edilen Nüzul

\begin{tabular}{|c|c|c|c|c|c|c|c|c|c|c|}
\hline \multirow{3}{*}{$\Xi$} & \multirow{3}{*}{ 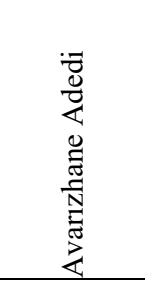 } & \multicolumn{5}{|c|}{ Tahakkuk Ettirilen } & \multicolumn{3}{|c|}{ Teslim Edilen } & \multirow[b]{3}{*}{ 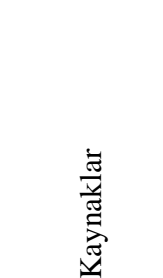 } \\
\hline & & \multicolumn{2}{|c|}{ Şair (Arpa) } & \multicolumn{2}{|c|}{$\begin{array}{l}\text { Dakik (Un) / } \\
\text { Buğday }\end{array}$} & \multirow{2}{*}{ 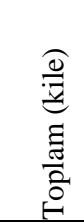 } & \multirow[b]{2}{*}{$\begin{array}{l}\frac{0}{\pi} \\
\underset{z}{z} \\
\frac{\pi}{2}\end{array}$} & \multirow[b]{2}{*}{$\underset{\frac{\partial}{g}}{\frac{\partial}{g}}$} & \multirow{2}{*}{ 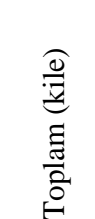 } & \\
\hline & & 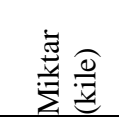 & 䒕 & 穿 & 芯 & & & & & \\
\hline 1580 & $-/-$ & $-/ 1708$ & $3 / 4$ & $-/ 569$ & $1 / 4$ & 2277 & 1514 & 295 & 1.809 & $\begin{array}{l}\text { KK.2553: } \\
12\end{array}$ \\
\hline 1617 & $1171 / 360$ & - & - & - & - & 1562 & - & - & 1.562 & $\begin{array}{l}\text { MKF27423: } \\
\text { 51-52 }\end{array}$ \\
\hline $1635-36$ & $1017 / 327$ & $3.051 /-$ & $3 / 4$ & $\begin{array}{l}1.017 \\
/-\end{array}$ & $1 / 4$ & 4068 & 3051 & $\begin{array}{l}101 \\
7\end{array}$ & 4.068 & $\begin{array}{l}\text { MKF } \\
\text { 27445: } 156\end{array}$ \\
\hline $1637-38$ & $1012 / 324$ & $\begin{array}{l}3036 / \\
972\end{array}$ & $3 / 4$ & $\begin{array}{l}1.012 \\
/ 324\end{array}$ & $1 / 4$ & 4048 & 2721 & 903 & 3.624 & $\begin{array}{l}\text { MAD 4347: } \\
73\end{array}$ \\
\hline
\end{tabular}

Tablo 1'den anlaşıldığ üzere Sinan Paşa'nın 1580 yılındaki doğu seferi ile IV. Murad'ın 1635-36 yılındaki Revan ve 1638-39 tarihindeki Bağdat seferleri esnasında Malatya kazas1/sancağından istenen nüzul zahiresinin 3/4’ü hayvan 
yemi olarak kullanılan şair yani arpa, 1/4’ü dakik yani un olarak tahakkuk ve tahsil edilmiştir. 1580 yılında Malatya kazasından toplam 2.277 kile (1.708 kilesi arpa, 569 kilesi un olmak üzere) nüzul zahiresi talep edilmiştir. Ancak bu zahirenin 1.809 kilesi (1.514 kile arpa, 295 kile un) teslim edilebilmiştir (KK.d., 2553: 12). 1026/1617 yılına ait nüzul zahiresi tevzi defterinde Malatya livasından istenen zahirenin un ve arpa olarak miktarı yazılmamış ikisinin yekûnu 1.562 kile olarak kaydedilmiştir. $\mathrm{Bu}$ tevziatta nüzulhane başına yaklaşı 1,4 kile zahire tarh edilmiştir (D.MKF.d., 27423: 52). Burada istenen arpa miktarının, un/buğdayın üç katı kadar olmasının sebebi, yem olarak fazla miktarda arpa tüketen ordudaki yük ve binek hayvanlarının sayıca fazla olmasından kaynaklanmaktadır (Türkmen, 2002: 132-33). Merkezi hükûmet, muhtemelen buğdayı temizlemek, ögütüp una çevirmek ve elemek gibi külfetlerden uzak durarak ordunun intikal hızını yavaşlatmamak için reayadan buğdaydan ziyade un talebinde bulunmaktaydı (İşbilir, 1996: 15; Küçük, 2007: 70). Ancak ambarlarda depolanacaksa o zaman buğday olarak istemekteydi. Nitekim Revan seferi lojistiği kapsamında 1045/1635-36 senesi için Malatya livasının yedi kazasından (Malatya, Kâhta, Şure, Gerger, Taşabad, Behisni ve Hısn-1 Mansur-SamsadBezeki kazaları) un yerine buğday talep edilmişti. Bu sene için sancaktaki kazaların her bir avarızhanelerinden 20 tam kuruş üzerinden nakden tahsil edilmişken tekrar yerinde aynî zahire teslim edilmesi ferman edilmiştir. Neticede nakdi 20.340 kuruş ile satın alınan 4.068 kile zahirenin tamamı tayin edilen mahalde yetkililere teslim edilmiştir. Bu hububatın 3.051 kilesini oluşturan ve kaza kadılarının mekkâreciler (nakliyeci) vasıtasıyla harp sahasına gönderdikleri arpa, nüzul eminine; 1.017 kilesini oluşturan hınta yani buğday ise mubayaa emini tezkeresi ile Revan kalesine teslim edilmişti (D.MKF.d., 27445: 63-64, 156-57). 1048/1638-39 y1lına mahsuben sadece 324 avarızhanesi olan Malatya kazasından 972 kile arpa, 324 kile de un aynı şehir sakinlerinden Arslan Çavuşzade Zeynel eliyle peyderpey tahsil edildikten sonra 31 Ekim 1638- 2 Ocak 1639 tarihleri arasında parça parça orduya teslim edilmiştir (MAD.d., 4347: 73).

Osmanlı Devleti'nin zamana, şartlara, ihtiyacına ve bölgelerin ekonomik vaziyetine göre vergi mükelleflerinden avarızhane başına talep ettiği nüzul miktarı farklılık göstermekteydi. Hatta aynı sene içinde de olsa farklı kaza ve livalara farklı oranlar ve miktarlar tayin edebilmekteydi. Mesela, 1582,1585 ve 1588 senelerinde Anadolu, Karaman, Haleb ve Şam eyaletlerinde olduğu gibi Malatya sancağının dâhil olduğu Zülkadriye eyaletinde de nüzul, her 30 haneden İstanbul ölçüsü ile 1 müd yani 1,5 avarızhanesinden 1 İstanbul kilesi hesabıyla tahsil edilmiştir (Güçer, 1964: 76). Daha önce geçtiği üzere aynî nüzul, 1045/ 1635-36 ve 1048/1638-39 tarihlerinde Malatya livasında avarızhane başına 4 kile olarak tarh ve tahsil edilmişti. 1048/1638-39 senesinde Anadolu eyaletinde nüzulhane başına 2,5 kile, diğer eyaletlerde 4 kile talep ve tahsil edilirken bakaya kalan kısmı ise bedel olarak alınmıştır (MAD.d., 4347: 80). Keza Veziriazam Halil Paşa tarafından 1036-1037/1627-1628 senesi için hazırlatılan nüzul tevzi 
defterine göre ise Malatya'nın dâhil olduğu Maraş ile Rum, Karaman, Haleb, Şam-1 Şerif, Trablusşam, Adana, Diyarbekir, Erzurum ve Trabzon eyaletlerinde avarızhane başına 24 kile nüzul zahiresi ihracı emredilmiştir. Ancak o yıl Malatya kazasında zahire olarak değil nüzulhane başına 932 akçeden nakit olarak tahsil edilmiştir (MAD.d., 6634: 21).

İncelenen dönem içerisinde Malatya livasının da bulunduğu Zülkadriye eyaleti, Devlet'in özellikle şark seferlerinde ordunun ihtiyacı olan nüzul zahiresinin temini anlamında önemli bir bölge niteliğindeydi (A.DVNSMHM.d., 55: 203; A.DVNSMHM.d., 63: 27, 34). Halktan nüzul adı ile talep edilen bu zahire, sürsat zahiresinin aksine hareket halindeki orduların menzillerine değil, hükûmet tarafından stratejik noktalarda bina edilen ambarlara konmakta ve sınır boylarında savaşan ordu birimlerine teslim edilmekteydi. Nitekim 1580 yılında Zülkadriye eyaletine tarh edilmiş olan 44.305 kile nüzulün 14.263 kilesi hudut gerisindeki kalelere teslim edilmiş, 15.461 kilesi ise savaşan ordulara tevzi edilmiştir. Bu sene Malatya kazasına tarh edilen 2.277 kile (1.708 kilesi arpa, 569 kilesi un olan) zahirenin ancak 1.809 kilesi (1.514 kile arpa ve 295 kile un) kaza naibi Molla Ali Halife tarafindan ordu birliklerine teslim edilmiştir (KK.d., 2553: 12-14; Güçer, 1964: 76). Aynı şekilde 996/1587-88 senesinde serdar Ferhat Paşa zamanında gerçekleştirilen Gence ve Karabağ seferi dolayısıyla Zülkadriye, Anadolu, Karaman, Rum, Diyarbekir ve Haleb eyaletlerinden teslim alınan nüzule ait defterin tetkikinden, her ne kadar Malatya kazasına nüzul tarh edildiği belirtilmemişse de, hububatın cepheye taşındığı ve orada kısmen Gence ve Gori kalelerine teslim edildiği, kısmen de savaşan birliklere tevzi edildiği anlaşılmaktadır (MAD.d., 457: 105-09). IV. Murad'ın 1635 tarihinde çıktığ Revan seferi sırasında Haleb, Diyarbekir, Maraş, Ayntab, Malatya, Adana ve Delvin kazalarından toplanan 31.529 kile zahirenin 7.892,5 kilesi Revan Kalesi'nde depolanmıştı (D.MKF, 15/56; Polat, 2015: 404). Keza aynı hükümdarın 1638'deki Bağdat seferi mühimmatı için 1048/1638-39 senesine mahsuben Rum, Karaman, Anadolu, Diyarbekir, Erzurum ve Rakka eyaletleri ile birlikte Maraş eyaletinin 33.651,25 avarızhanesinden talep edilen 100.589,75 kile nüzulün 96.548,25 kilesi, kaza kadıları ve reaya tarafindan 15 Ekim 1638 - 03 Şubat 1639 tarihleri arasında harp sahasında aynen orduya teslim edilmiştir (MAD.d., 4347: 80; Güçer, 1964: 85). Harp sahasına yakın yerlerde nüzul emini ve diğer yetkililere teslim edilen hububat, gerektiğinde askeri neferata dağıtılırdı. Nitekim 10 Kasım 1625 tarihinde nüzul emini Hamza Efendi’ye, Malatya nüzulünden top arabaları ve mehterlerin atlarının ihtiyacı olan arpayı vermesi hakkında buyuruldu gönderilmişti (AE.SMRD.IV. 6-576).

İşler her zaman yolunda gitmemiş görünüyor. Hususan 17. yüzyılın ilk çeyreğinde Celali isyanlarının ve eşkıyalığın iyice arttığı sıralarda bölgenin perişan ve perakende olan reayasının önemli bir kısmının yer değiştirmesinden dolayı geride kalanların eski avarızhane hesabı üzerinden kendilerine yüklenilen 
nüzul tekâlifini yerine getirmede zorlandıklarını arşiv vesikalarından anlamak zor değildir. 1617 yılında Malatya livasının 1.255 avarızhanesinden ancak 1.171 tanesinden zahire ihraç edilebilmiştir (D.MKF.d., 27423: 52).

16. yüzyılda avarızın başına gelen nakdileşme ve olağanlaşma süreci 17 . yüzyıl ortalarında nüzulün başına gelmiş, o da biraz gecikmeyle beraber avarızın akıbetine uğramıştır. Bu dönemde bir taraftan savaş ve askerî usullerde meydana gelen gelişme ve değişimler, diğer taraftan 16. yüzyılın sonlarında batıda ve doğuda Avusturya ve İran ile girişilen uzun soluklu ancak neticesiz savaşların ağır masrafları devletin askerî ve mali sistemini tahrip etti. Ülke içindeki anarşi ve terör ortamından dolayı külliyetli nüfusun yer değiştirmesi sonucu üretimin azalması ve büyük çoğunluğu ürüne bağlı olan normal vergilerin tahsil edilememesi gibi sebeplerle Osmanlı maliyesinin artan nakit ihtiyacı nüzul vergisini hem olağan hem de nakdî vergiler sırasına sokmuştur. Nüzul artık daimî olmakla kalmayıp bu tür vergilerin en ağırlarından biri olmuştur (Mc Gowan, 1981: 1327-28). Bu tetkikte bahse konu edilen dönemde, tespit edilebildiği kadarıyla, Malatya livasında nüzul sadece üç kez aynî olarak, onlarca defa ise bedel olarak tahsil edilmiş.

Esasen Merkezi hükûmetin, savaşan askerlerinin ihtiyacını temin ettikten sonra özellikle savaş alanına uzak mahallerden külli zahirenin nakil ve emniyetinin de zorluğunu göz önüne alarak bu vergiyi, nakden almayı tercih ettiği önceki satırlarda ifade edilmişti. Ülkede para ekonomisinin zamanla gelişmesi de nüzulün bedel olarak alınmasını yaygınlaştıran diğer bir faktör olmuştur. Kadılara konu ile ilgili gönderilen emirlerde sefer güzergâhına uzakta kalan reayadan nüzulün nakden alınmasının onlara bir kolaylık ve merhamet olduğu sik sik vurgulanmıştır (MAD.d., 3441: 1; AŞS, 15: 12). Hakikaten de mükellefler, menfaatlerine olan bu yöntem sayesinde kendilerinden talep edilen zahirenin ihracı, taşıma masraf ve külfetleri ile yol ve teslim esnasında oluşacak risklerden kurtulmuş oluyorlardı (Küçük, 2007: 71). Bu yeni usulde kendi üzerlerine düşen meblağı görevli mübaşire teslim edince sorumlulukları bitmekteydi.

Nüzul vergisi bedel olarak tarh veya talep edildiğinde, onun tahsil ve hazineye teslimi merkezi hükûmet tarafindan tayin edilip kendilerine emir ve defter verilen tahsildarlar, resmi ifadesiyle mübaşir denen görevliler, aracılığıyla gerçekleştirildiğine daha önce değinilmişti. Şayet başka bir üst unvanı bulunmuyorsa, bunların unvanları vesikalarda genellikle "ağa" olarak zikredilmiştir. Ekserisi askerî zümreden, yani çeşitli kurumlarda resmi bir vazifeyi ifa eden ulûfeli memurlar arasından, seçilmekle beraber bazen de üst kademedeki devlet görevlilerine intisap etmiş İstanbul veya taşrada ikamet eden kimselerden de tayin edilmişlerdir. Mahalli kadı ve diğer yetkililerin görevli mübaşire yardımcı olmaları ve nüzul sürecinin hakkaniyet üzere azami dikkat ve ihtimam içerisinde gerçekleştirilmesi gönderilen emir ve hükümlerde daima 
vurgulanmıştır. İncelenen belgelerden Malatya nüzul bedellerini tahsil eden mübaşirlerin isim ve kimlikleri tespit edilenler aşağıda 2 numaralı tabloda gösterilmiştir. $\mathrm{Bu}$ tablodan da görüleceği üzere Malatya sancağı nüzul bedellerinin tahsili işine 1644-45 senesinde Maraş valisi Vezir Tekeli Mustafa Paşa (D.MKF.d., 27467: 11), 1648-49 senesinde gümrük emini Hasan Ağa (MAD.d., 3838: 42), 1654-55 y1lında İstanbul Ağa's1 Mustafa A ̆̆a (KK.d., 2621: 21, 55; KK.d., 2623: 43-44), 1656-57 tarihinde Diyarbekir muhafizı Hasan Paşa kap1 kethüdası Köse Ali Ağa (KK.d., 2627: 46), 1659-60 senesinde Defterdar Paşa'ya tabi olup Divriği' de sakin Mehmed Ağa (MAD.d., 3857: 23), 1663-64'te İbrahim Paşa'nın kardeşi İsmail Ağa (MAD.d., 3748: 15), 1671-72 senesinde de Budin Beylerbeyi merhum Koca Köse Mehmed Paşa'nın voyvoda kethüdası Zülfikar Ağa (MAD.d., 2790: 51) mübaşir olarak atanmıştır. Yine aynı vazife için 1646-47 yılında İpşir Mustafa Çelebi vasıtasıyla Mustafa Bey (KK.d., 2613: 12); 1650 yılında Dergâh-1 Âli Kapıcılar Kethüdası Salih Ağa marifetiyle Kengıri sakinlerinden Hasan Bey (KK.d., 2618: 23); 1662-63'te ise İstanbul'da oturan Paşazade Salih aracılığıyla akrabasından İbrahim Ağa (MAD.d., 3157: 51) tayin edilmiştir. Bazı mübaşirlerin birden fazla görevi yüklendikleri de vaki olmaktaydı. Örneğin bunlardan Mustafa Ağa 1654-55, Köse Ali Ağa 1656-57 ve Zülfikar Ağa ise 1671-72 yılına ait Malatya sancağı nüzul bedelleri ile birlikte aynı livanın avarız akçelerinin reayadan tahsil ve hazineye teslim işini de üstlenmişti. Keza, Hasan Bey, 1650 yılında Malatya'nın yanı sıra Maraş ve Ayntab sancaklarının nüzul bedellerini de deruhte etmiş̧i (KK.d., 2618: 23). 1660'lı yılların sonlarından itibaren ise bu görev, genellikle arpa eminlerinin uhdesine verilmiştir. Bu durumda tabii olarak İstabl-1 amireye ocaklık tayin edilen birden fazla liva ve kazanın avarız akçesi ile birlikte nüzul bedeli hatta başka vergilerin tahsil işi de onların uhdesinde yer almaktaydı.

Tablo 2. 17. Yüzyılda Malatya Livasına Vazifelendirilen Nüzul Mübaşirleri

\begin{tabular}{|c|c|c|c|}
\hline \multicolumn{2}{|l|}{ Mübaşirin } & \multirow{2}{*}{ Açıklama } & \multirow{2}{*}{ Kaynaklar } \\
\hline Ad1 & Görev Tarihi & & \\
\hline Hasan Bey & 1617 & Başbaki kulu & $\begin{array}{l}\text { MKF 27423: 51- } \\
52\end{array}$ \\
\hline $\begin{array}{l}\text { Süleyman Yusuf } \\
\text { Murtaza }\end{array}$ & $1624-25$ & Sipahi & MAD 3198: 17 \\
\hline Mustafa Ağa & $1634-35$ & Sipahi oğullarından & MKF 27445: 48 \\
\hline Mehmed İbrahim Bekri & $1626-27$ & Sipahi oğullarından & MAD 3862: 79 \\
\hline Mehmed Abdullah & $1635-36$ & Sipahi oğullarından & MKF 27445: 63 \\
\hline $\begin{array}{l}\text { Arslan Çavuşzade } \\
\text { Zeynel }\end{array}$ & $1638-39$ & Malatya sakini & MAD 4347: 73 \\
\hline $\begin{array}{l}\text { Vezir Tekeli Mustafa } \\
\text { Paşa }\end{array}$ & $1644-45$ & Maraş Valisi & $\begin{array}{l}\text { MKF 27467: 11; } \\
\text { MKF 27468: } 69\end{array}$ \\
\hline Mustafa Bey & $1646-47$ & $\begin{array}{l}\text { Eski Gedik paşa } \\
\text { hamamcısı }\end{array}$ & KK 2613: 12 \\
\hline
\end{tabular}




\begin{tabular}{|c|c|c|c|}
\hline Ebubekir & $1647-48$ & Silahtar & MAD 3048: 24 \\
\hline Mehmed Ăga & $1647-48$ & Hazinedarbaşı & \\
\hline Hasan Ağa & $1648-49$ & Gümrük emini & MAD 3838: 42-43 \\
\hline Hasan Bey & 1650 & Kengiri sakinlerinden & KK 2618: 23 \\
\hline Mehmed Çelebi & $1651-52$ & $\begin{array}{l}\text { Melek Ahmed Paşa } \\
\text { adamı }\end{array}$ & İE.ML. 8-655 \\
\hline Boyacı Hasan Ağa & $1653-54$ & & MAD 2989: 51 \\
\hline Ali Ăga & $1653-54$ & $\begin{array}{l}\text { Hassa bostancılar } \\
\text { odabaşısı }\end{array}$ & MAD 2989: 51 \\
\hline Mustafa Ağa & $1654-55$ & İstanbul ağası & $\begin{array}{l}\text { KK 2621: 21, } 55 \\
\text { KK 2623: 43-44 }\end{array}$ \\
\hline Köse Ali Ağa & $1656-57$ & $\begin{array}{l}\text { Diyarbekir muhafizı } \\
\text { Hasan Paşa kapı } \\
\text { kethüdası }\end{array}$ & KK 2627: 46 \\
\hline Hacı Osman Bey & $1658-59$ & $\begin{array}{l}\text { İstanbul'da sakin, } \\
\text { Eğinli, Sipahi }\end{array}$ & $\begin{array}{l}\text { MAD 3853: 42; } \\
\text { MAD 3028: } 117\end{array}$ \\
\hline Mehmed Ağa & $1659-60$ & $\begin{array}{l}\text { Divriği'de sakin, } \\
\text { Defterdar Paşa'ya tabi }\end{array}$ & MAD 3857: 23 \\
\hline Osman Ağa & 11.6.1661 & & $\begin{array}{l}\text { SMMD.IV. 90- } \\
542\end{array}$ \\
\hline İbrahim Ağa & $1662-63$ & $\begin{array}{l}\text { Fettah Paşazade } \\
\text { akrabası }\end{array}$ & $\begin{array}{l}\text { MAD 3157: } 51 \\
\text { KK 2635: } 41\end{array}$ \\
\hline İsmail Ağa & $1663-64$ & $\begin{array}{l}\text { İbrahim Paşa'nın } \\
\text { kardeşi }\end{array}$ & $\begin{array}{l}\text { MAD 3748: 9, } 15 \\
\text { MAD 3067: } 20\end{array}$ \\
\hline Mehmed Çelebi & $1664-65$ & Çavuş Kâtibi & MAD 3354: 7 \\
\hline Süleyman Efendi & $\begin{array}{l}1667-68 \\
1669-70 \\
1674-75\end{array}$ & Arpa emini & $\begin{array}{l}\text { MAD 3836: 47; } \\
\text { KK 2651: 24; } \\
\text { MAD 3856: 44; }\end{array}$ \\
\hline Zülfikar Ağa & $1671-72$ & $\begin{array}{l}\text { Mehmed Paşa'nın } \\
\text { voyvoda kethüdası }\end{array}$ & MAD 2790: 51 \\
\hline Mustafa Efendi & $1672-73$ & Arpa emini & $\begin{array}{l}\text { MAD 2412: 39; } \\
\text { KK 2659: } 49\end{array}$ \\
\hline Ali Efendi & $\begin{array}{l}1675-76 \\
1679-80\end{array}$ & Arpa emini & $\begin{array}{l}\text { KK 2665: 22; KK } \\
\text { 2668: 20-21; } \\
\text { MKF27564: } 2\end{array}$ \\
\hline Mahmud Efendi & $1678-79$ & Arpa emini & $\begin{array}{l}\text { MAD 3809: 30; } \\
\text { KK 2688: } 2\end{array}$ \\
\hline İbrahim Efendi & $\begin{array}{l}1688-89 \\
1689-90\end{array}$ & Arpa emini & $\begin{array}{l}\text { MAD 3167: } 77 \\
\text { MAD 9480: } 82\end{array}$ \\
\hline Süleyman & $1692-93$ & & $\begin{array}{l}\text { MKF 27700, 4; } \\
\text { MKF 27714: } 2\end{array}$ \\
\hline el-hac Hasan Efendi & 1694- 98 & Arpa emini & $\begin{array}{l}\text { MAD 3829: 94- } \\
\text { 96; MKF 27782: } \\
\text { 3-4 }\end{array}$ \\
\hline Mustafa Efendi & $\begin{array}{l}\text { 1695-96, } \\
1696-97\end{array}$ & Arpa emini & MAD 3807: 39, 42 \\
\hline
\end{tabular}


Mübaşirlerin avarı-1 divaniye bedellerini iltizama alabilmeleri için kendilerine delalet edecek itibarlı veya resmi kişilerin yanı sıra güçlü kefillerinin de bulunması gerekirdi. Bunlar toplayacakları meblağın bir kısmını hazineye peşin öderken gerisine düzenlenen senetler ilgili birimlerde sağlamca hıfzedilirdi (KK.d., 2657: 51). Mesela 1069/1658-59 tarihinde Malatya, Rakka ve Biretü'lFırat (bugünkü Birecik) livalarının nüzul bedellerinin toplanması işi, hazineye bir kısmını peşin yatıran Hacı Osman Bey'e tevcih edilmişti (MAD.d., 3855: 47). Keza 1082/1671-72 yılına ait Malatya livasının avarız ve nüzul akçelerinin tahsilini, hazineye 150.000 akçelik peşinat yatıran Zülfikar Ağa üstlenmiştir (MAD.d., 2790: 51). Aynı şekilde Malatya sancağının toplam 965.980 akçelik 1075/1664-65 senesi avarız ve nüzul bedellerinin tahsili görevi, iki yük (200.000) akçe peşin ile 22 Mart 1665 tarihinde Mehmed Çelebi adındaki kimseye verilmiştir (MAD.d., 3354: 7).

Malatya ahalisinden 17. Yüzyıl boyunca bedel olarak talep edilen nüzul vergisi ile ilgili olarak Osmanlı arşivinin bu döneme ait Bedel-i Nüzulhane Defterlerinden elde edilen verileri, anlamlı kılmak için, 3 numaralı tablo hazırlanmıştır. $\mathrm{Bu}$ tablo incelendiğinde yüzyılın ikinci çeyreğinden itibaren istisnai bir iki uygulama hariç bedel olarak tahsil edilen nüzul vergisinin, Malatya livası kazalarında avarızhane/nüzulhane başına çok farklı miktarlarda alındığ görülmektedir. $\mathrm{Bu}$ dönem içerisinde Malatya halkı en düşük nüzul bedelini 1054/1644-45 yılında avarızhane başına 3,5 kâmil kuruş (280 akçe) olmak üzere toplamda 3.531,5 kâmil kuruş (282.520 akçe) olarak ödemiştir. 1.009 nüzulhanesi olan ve 282.520 akçelik (3.531,5 kâmil kuruş) bir yekûn oluşturan Malatya livasındaki tüm kazaların nüzul akçeleri, o tarihte Girit üzerine düşünülen sefer-i hümayun mühimmatı için talep edilmiştir. Halk bu sene mübaşir ücreti için de ayrıca hane başına 10 akçe vermiştir (D.MKF.d., 27467: 11). Malatya livasındaki vergi mükellefleri, bu dip değerden sonra ikinci en düşük miktarı 1059/1649-50 ve 1065/1654-55 yıllarına mahsuben nüzulhane başına 300 akçeden tediye etmiştir. Zikredilen senelerde nüzul bedelinin düşük alınmasının sebebi, arşiv belgesinde Sultan'ın orduların başında sefere çıkmayıp tayin ettiği serdarların orduya komuta etmesi gösterilmiştir. Nitekim Malatya sancağındaki kadılara, bu hususun da belirtildiği, 9 Ocak 1658 tarihinde ilginç bir emir gönderilmiştir. Bu emirde Sultan IV. Murad'ın şark seferleri gerçekleştirildiğinde Rumeli taraflarındaki kazaların avarızhanelerinden mekkari bedeli adıyla 600 akçe nüzul bedeli alındığının hazine-i amire defterlerinde kayıtlı olduğu, ancak o zamandan beri Padişah'ın bizzat sefere gitmemesinden dolayı nüzul bedelinin yarısı üzerinden tarh ve tahsil edildiği anlatılır. Fakat bu sene bizzat hünkârın ordunun başında sefere çıkacak olmasından ötürü 1068/1657-58 senesi için daha önce 300 akçe üzerinden istenen ve toplanıp hazineye teslim edilen nüzul bedellerinin 600 akçeye tamamlanması için gönderilen mübaşir marifetiyle kazalarındaki avarızhane başına üç yüzer akçenin daha acilen toplanarak ordu hazinesine gönderilmesi emredilmiştir (MŞS, 1: 172). Ancak diğer örnekler göz önüne 
alındığında bunun genel bir uygulama olmadığı anlaşı1ıyor. Yani hükümdarın savaşa iştirak etmediği zamanlarda daha düşük bir nüzul talep edildiği genel bir kaide olarak işlememiştir. Padişah'ın katıldığı seferlerin daha külfetli olduğu muhakkak olsa da diğer seferlerde de hatta savaşların olmadığı zamanlarda da nüzul bedellerinin avarızhane başına 500-600 akçe bandında alınmaya devam edildiği görülmektedir. Aslında yukarıdaki örnekten bir önceki yılda da ona benzer başka bir tatbikat yani önce nısıf olan 300 akçeden nüzulün nakden talep ve tahsil edilmesi daha sonra ihtiyaçlar ileri sürülerek 600 akçeye tamamlanması 1067 nüzulünde de yaşanmıştır. Arşivdeki bir sürsat tevzi defterinde kayıtlı Haziran 1657 tarihli bir hükmün girişinde sadrazam Köprülü Mehmed Paşa'nın Venedik üzerine karadan ve denizden yapmayı düşündüğü sefere gidecek asker için külli zahire tedariki gerektiği vurgulanmıştır. Devamında Sultan Murad dönemi uygulaması anlatıldıktan sonra o yıl için daha önce Anadolu cihetindeki reayadan her avarızhaneden üçer yüz akçe nüzul bedeli talep ve tahsil edildiği ancak düşünülen Venedik seferi için çok miktarda zahireye ihtiyaç ortaya çıtığından kalan üçer yüz akçe nüzul bedeli karşılığında tüm halktan bu kez sürsat bedeli talep edilmiştir. Talep edilen meblağ karşıllığında gerek avarızhaneye bağlı olanlar gerek muaf-müsellem olan herkesten sürsat zahiresi bedellerinin tahsil edilerek ordu hazinesine aktarılması emredilmiştir (KK.d., 2624: 84-85). Bu tahvilde yani nüzul bedeli yerine sürsat bedeli istenmesi, cüzi de olsa halkın yükünü azaltmıştır. Çünkü sürsat yükümlülüğüne daha geniş halk kitleleri iştirak ettirilmekteydi.

Malatya sancağı kazalarındaki avarızhane başına en yüksek nüzul bedelinin, 1037/1627-28, 1038/1628-29 ve 1047/1637-38 senelerinde bu dönemde cereyan eden seferlerin masraflarını karşılamak için, alındığı arşiv kayıtlarında müşahede edilmektedir. Bu kapsamda 1627 tarihinde isyan içinde olan Erzurum Valisi Abaza Mehmet Paşa'nın tenkili için sevk edilen askerin harcamaları cihetine sancağın Malatya, Kâhta, Şure, Taşabad, Behisni ve Hısn-1 Mansur kazalarında hane başına 932 akçe; Gerger kazasında ise 560 akçe ( 7 kâmil kuruş) nüzul bedeli tarh ve tahsil edilmiştir (MAD.d., 6634: 21). Merkezi idare, bu miktarın neredeyse iki misli nüzul akçesini, Hüsrev Paşa'nın 1038/1628-29'da yürüttüğü şark ve IV. Murad'ın 1047/1637-38 senesinde gerçekleştirdiği Bağdat seferleri esnasında tahakkuk ettirmiştir. Bu tarihlerde vergi mükelleflerinden avarızhane başına 20 tam kuruş (1.600 akçe) nüzul bedeli tarh ederek 1.018 avarızhaneye malik livadan tamı tamına 1.627.200 akçelik (20.320 kâmil kuruş) bir gelir beklentisine girmişti. Bu sırada sadece Malatya kazasından 526.400 akçelik (6.580 kâmil kuruş) bir para tahsilatı yapılacaktı (MAD.d., 6633: 45-46; MAD.d., 7104: 42). Ancak Devletin resmi belgelerinin münderecatından buradaki vergi mükelleflerinin zaman zaman zikredilen yüksek oran/miktarlardaki bedelleri ödemekte zorlandıkları dolayısıyla borçlarının bir kısmını tediye edemedikleri anlaşılmaktadır. Mesela, kendilerinden 1044/1634-35 y1lına mahsuben nüzul akçesi için nüzulhane başına 16 ve rub tam kuruş olarak istenen ve yekûnu 
16.526,5 tam kuruş (1.652.650 akçe) tutan meblağın 500,5 kuruşluk (50.050 akçe) kısmını ödeyemeyince bu miktar bakaya kalmıştı (D.MKF.d., 27445: 49). Osmanlı Devleti, istisnai bu uç değerler dışında ordunun hudutlarda savaştı̆̆ 1 dönemlerde Malatya' daki reayadan genellikle hane başına 600 akçe, diğer normal zamanlarda ise 400-500 akçe gibi daha düşük oranda nüzul bedeli talep etmiştir. 80-90 senelik gibi uzun bir zaman diliminde avarızhane başına talep ve tahsil edilen nüzul akçesi miktarında anormal bir değişikliğin olmadığı nispi bir istikrar olduğu incelenen arşiv belgelerinden anlaşılmaktadır.

Tablo 3. 17. Yüzyıl Boyunca Malatya Livası Nüzulhane Sayıları ve Nüzul Bedelleri

\begin{tabular}{|c|c|c|c|c|c|c|}
\hline \multirow{2}{*}{ Yil } & \multicolumn{2}{|c|}{ Nüzulhane adedi } & \multirow{2}{*}{$\begin{array}{l}\text { Nüzulhanesi } \\
\text { başına } \\
\text { ödenen (akçe/ } \\
\text { Kuruş) }\end{array}$} & \multicolumn{2}{|c|}{$\begin{array}{l}\text { Talep Edilen toplam nüzul } \\
\text { bedeli tutarı (akçe/Kuruş) }\end{array}$} & \multirow{2}{*}{ Kaynaklar } \\
\hline & $\begin{array}{l}\text { Malatya } \\
\text { Livası }\end{array}$ & $\begin{array}{l}\text { Malatya } \\
\text { Kazası }\end{array}$ & & $\begin{array}{l}\text { Malatya } \\
\text { Livası }\end{array}$ & $\begin{array}{l}\text { Malatya } \\
\text { Kazası }\end{array}$ & \\
\hline 1034/1624-25 & 1.171 & 360 & 400 & $468.400 /-$ & $144.000 /-$ & MAD 3198: 17-8 \\
\hline 1036/1626-27 & 1.096 & 354 & 600 & 657.600/- & 212.400/- & MAD3862:79-80 \\
\hline 1037/1627-28 & 1.043 & 329 & 932 & $972.076 /$ & 306.628 & MAD 6634: 21 \\
\hline 1038/1628-29 & 1.018 & 329 & 1.600/20 K.k. & $\begin{array}{l}1.627 .200 \\
/ 20.320\end{array}$ & $\begin{array}{l}526.400 / \\
6.580\end{array}$ & $\begin{array}{l}\text { MAD 6633: 45- } \\
46\end{array}$ \\
\hline 1044/1634-35 & 1.017 & 329 & -/16 R 1 K.k & $-/ 16.526,5$ & $-/ 5.3461 \mathrm{R}$ & MKF27445: 48 \\
\hline $1045 / 1635-36$ & 1.015 & 327 & -/20 T.k. & $-/ 20.340$ & $-/ 6.440$ & MKF27445:63-4 \\
\hline 1047/1637-38 & 1.012 & - & -/20 T.k & $-/ 20.240$ & - & MAD 7104: 42 \\
\hline 1054/1644-45 & 1.009 & 324 & $\begin{array}{l}280 / \\
3,5 \mathrm{~K} \cdot \mathrm{k}\end{array}$ & $\begin{array}{l}282.520 / \\
3.531 \mathrm{~K} . \mathrm{k} .\end{array}$ & $\begin{array}{l}90.720 / \\
1.134\end{array}$ & $\begin{array}{l}\text { MKF 27467: 11; } \\
\text { MKF 27468: } 68\end{array}$ \\
\hline 1056/1646-47 & 1.009 & 324 & $\begin{array}{l}400 / \\
5 \mathrm{~K} . \mathrm{k} .\end{array}$ & $\begin{array}{l}403.600 / \\
5.045\end{array}$ & $\begin{array}{l}129.600 / \\
1.620\end{array}$ & KK 2613: 12 \\
\hline 1057/1647-48 & 1.009 & 324 & $\begin{array}{l}400 / \\
5 \mathrm{~K} . \mathrm{k} .\end{array}$ & $\begin{array}{l}403.600 / \\
5.045\end{array}$ & $\begin{array}{l}129.600 / \\
1.620\end{array}$ & MAD 3048: 24 \\
\hline 1059/1649-50 & 1.007 & 322 & $400 /-$ & 402.800 & 128.800 & MAD 3838: 42 \\
\hline $1060 / 1650$ & 1.007 & 322 & 400 & 402.800 & 128.800 & KK 2618: 23 \\
\hline $1064 / 1653-54$ & 1.002 & 317 & 300 & $300.600 /$ & 95.100 & MAD 2989: 51 \\
\hline $1065 / 1654-55$ & 1.002 & & 300 & 300.600 & & $\begin{array}{l}\text { KK 2621: 55; } \\
\text { KK 2623: 43-44 }\end{array}$ \\
\hline 1066/1655-56 & 977 & 293 & 600 & 586.200 & 175.800 & MAD 3028: 117 \\
\hline 1069/1658-59 & 977 & 293 & 300 & 293.100 & 879.00 & $\begin{array}{l}\text { MAD 3855: } 47 \\
\text { MAD 3853: } 42\end{array}$ \\
\hline 1070/1659-60 & 977 & 293 & 500 & 488500 & 146.500 & MAD 3857: 23 \\
\hline 1073/1662-63 & $\begin{array}{l}967 \mathrm{R} \\
0,5\end{array}$ & $\begin{array}{l}276 \mathrm{R} \\
0,5\end{array}$ & 500 & 386.563 & 138.063 & $\begin{array}{l}\text { MAD 3157: 51; } \\
\text { KK2635: } 41\end{array}$ \\
\hline 1074/1663-64 & 967 & & 500 & 483.5639 & & MAD3748: 9, 15 \\
\hline 1075/1664-65 & 960 & & & 576.070 & & MAD 3354: 7 \\
\hline 1078/1666-67 & 967 & & 600 & 576.070 & & MAD3856: 44-5 \\
\hline 1082/1671-72 & $\begin{array}{l}967 \mathrm{R} \\
0,5\end{array}$ & $\begin{array}{l}276 \mathrm{R} \\
0,5\end{array}$ & 300 & 288.038 & 82.838 & $\begin{array}{l}\text { MKF 27520: 45; } \\
\text { MAD 2790: } 51\end{array}$ \\
\hline 1083/1672-73 & 967 & 276 & 600 & 576.070 & 165.675 & KK 2657: 51 \\
\hline
\end{tabular}

${ }^{9}$ Başka defterde bu yılın nüzul bedeli 576.075 akçe olarak kaydedilmiştir (MAD.d., 3067: 20). 


\begin{tabular}{|c|c|c|c|c|c|c|}
\hline $1085 / 1674-75$ & 967 & 276 & 600 & 576.075 & 165.675 & KK 2662: 46 \\
\hline 1086/1675-76 & 967 & 276 & 600 & 576.075 & 165.675 & KK 2668: 20-21 \\
\hline 1089/1678-79 & 960 & - & 600 & 576.075 & - & KK 2688: 2 \\
\hline $1090 / 1679-80$ & 960 & - & 600 & 576.075 & - & MKF 27564: 2 \\
\hline 1097/1685-86 & 960 & & -/5,5 E. k. & 5.237 E.k. & & MKF 27600: 22 \\
\hline 1098/1686-87 & 960 & & -/5,5 E. k. & 5.237 E.k. & & MKF 27613: 8 \\
\hline 1100/1688-89 & 68410 & - & 600 & $\begin{array}{l}410.400 / \\
3731 \mathrm{E} . \mathrm{k}\end{array}$ & & KK 2728: 65 \\
\hline $1102 / 1690-91$ & 684 & - & 600/ 5,5 E. k. & $\begin{array}{l}\text { 410.400/3. } \\
731 \text { E.k. }\end{array}$ & - & $\begin{array}{l}\text { MKF27708: 2-3; } \\
\text { MAD 3265: } 68\end{array}$ \\
\hline 1104/1692-93 & 684 & - & -/5,5 E. k. & 3.731 E.k. & - & $\begin{array}{l}\text { MKF 27665: 6; } \\
\text { MKF 27708: 2-3 }\end{array}$ \\
\hline $1106 / 1694-95$ & 684 & & 600 & $\begin{array}{l}410.400 / \\
3.731 \text { E. k. }\end{array}$ & & $\begin{array}{l}\text { KK 2762: 37; } \\
\text { MAD 3829: } 94\end{array}$ \\
\hline 1108/1696-97 & 649 & & 600 & $\begin{array}{l}389.400 / \\
3.540 \text { E.k. }\end{array}$ & & $\begin{array}{l}\text { MAD 3807: 41; } \\
\text { MKF 27776: } 6\end{array}$ \\
\hline 1109/1697-98 & $\begin{array}{l}924 \text { S } 2 \\
\text { R } 0,5\end{array}$ & & 600 & $\begin{array}{l}554.875 / \\
5.044\end{array}$ & & MKF 27782: 3 \\
\hline 1110/1698-99 & $\begin{array}{l}919,5 \mathrm{~S} \\
2 \mathrm{R} 0,5\end{array}$ & & 600 & $\begin{array}{l}\text { 552.175/ } \\
\text { 5.017 E.k. }\end{array}$ & & MKF 27782: 5 \\
\hline 1112/1700-01 & - & & - & 5.017 E.k. & & MKF 27842: 4 \\
\hline 1113/1701-02 & 919 S 2 & $270,5 \mathrm{~S}$ & $600 /$ & $551.875 /$ & $162.775 /$ & MKF 27853: 29; \\
\hline 1114/1702-03 & $\begin{array}{l}\text { R } 0,5 \\
-\end{array}$ & 2 R 0,5 & $\begin{array}{l}\text { 5,5 E.k. } \\
-\end{array}$ & $\begin{array}{l}\text { 5.017 E. k. } \\
\text { 5.017 E.k. }\end{array}$ & 1.488 E.k & $\begin{array}{l}\text { MAD 3091: } 21 \\
\text { MAD 3091: } 21 \text {; } \\
\text { MKF 27827: } 24\end{array}$ \\
\hline E.k.: Esedi kur & K.k.: & & S. & T.k & $\mathrm{k}$ & \\
\hline
\end{tabular}

Avarız türü vergilerin tahsilinde kullanılan esedi kuruş, kâmil kuruş ve zolatanın 17. yüzyıl boyunca yaklaşık \% 100 değer kazanması (Pamuk, 1999: 152) ve akçenin aynı oranda değerini yitirmesine rağmen Merkezi idare, düzenli tarh ettiği nüzul miktarını zaman içinde enflasyon oranında artırmamıştır. Aksine halkın ödeme hususundaki şikâyetlerini de nazara alan Padişah, onların hallerine merhameten nüzul bedeli miktarlarında zaman zaman tenzilatlar da yaparak onların daha fazla perişan olmasını bir nebze de olsa engellemiştir. Esasen Sultanların, memleketlerinde herhangi bir fütuhat veya bir muvaffakiyet meydana geldiğinde, buna bir şükran ifadesi olarak, reayanın vergi yüklerinde indirim yapmak suretiyle onlara ihsanda bulunması Osmanlı'nın kadim ve güzel bir âdetiydi. Mesela, Sultan IV. Mehmed, 1659 Haziran'ında çıkardığ fermanıyla ülke genelindeki Celâlî eşkıyasının başarılı bir biçimde temizlenmesinin şükür nişanesi olarak tüm Osmanlı memleketinde avarız-1 divaniye mükelleflerine yönelik genel bir af çıkardı. Bu kapsamda nüzul ile yükümlü kılınan reayanın 1070/1659-60 senesi için avarızhane başına ödemesi gereken alt yüzer akçe nüzul bedellerinden yüzer akçe $(\% 16,6)$ tenzilat yapılmasını emretmiştir. Fermanda bu işler için görevlendirilen mübaşirler,

${ }^{10} \mathrm{Bu}$ tarihlerde menzilci tayin edildiklerinden Malatya kazası avarızhanelerine nüzul bedeli tarh edilmemiştir. 
vergileri bu indirimli halleriyle talep ve tahsil edilmesi hususunda şiddetle ikaz edilmiş, hatta vergilerini daha önce 600 akçeden verenler varsa bunların fazlalıklarının iadesi kendilerine emredilmiştir (MAD.d., 3857: 2). Esaslı bir vergi barışı da yüzyılın sonunda imzalanan Karlofça anlaşmasından sonra gelmiştir. Uzun süredir devam eden ve külliyetli nakit ve zahire ihtiyacına sebep olan batı sınırlarındaki savaşların sona erdirilerek sulh devresine girilmesi ile Devlet, reaya üzerine daha önce saldığı sefer tekâlifinden vazgeçerek onları rahatlatmak istemiştir. Çıkan hatt-1 hümayunun çerçevesi oldukça geniş tutulmuştu. Nitekim bu fermana göre bundan sonra bedel-i sürsat, bedel-i beldar, ard (un) ve firın bedelleri gibi tekâlif-i seferiye reaya fukaralarından düşürülerek talep edilmeyecekti. Ayrica 1106, 1107, 1108 ve 1109 seneleri için daha önce tarh ve talep edilen vergilerin de şimdiye kadar tahsil olunandan başkası onlardan istenmeyecek ve bağışlanacaktı. Reaya üzerinde mali bir bahar havası estiren bu güzel kararların mahallinde uygulanması için tüm yetkililere 1699 baharının Nisan başlarında emr-i şerifler yazılmıştır (MAD.d., 3471: 1). Vergi indirimleri bazen de istenilen meblağın bir bölümünün, halkın tahammüllerinin olmadığını 1srarla bildirmesi üzerine, affedilmesi şeklinde gerçekleşirdi. Bunun bir örneği 1069/1658-59 senesinde Malatya livasının tarh edilen 586.200 akçelik nüzul bedelinin 146.550 akçesinin bağışlanmasıdır (MAD.d., 3028: 117). Buna benzer diğer bir örnek bir yıl sonra yani 1070/1659-60 tarihinde gerçekleşti. Padişah fermanı ile hükûmet bu kez 97.700 akçelik alacağından vazgeçmiştir (MAD.d., 3857: 23). Böylece ahali üzerinde ilkinde tam \%25'lik ikincisinde \%17’lik, hiç de küçümsenmeyecek, bir rahatlama sağlanmıştır. Bununla birlikte merkezî hükûmetin, yüzyılın sonlarında artık istikrar kazanan her avarızhanesi için 600 akçe nüzul bedeli oranını, maliyede takip ettiği fiskalizm ilkesi ${ }^{11}$ gereği, sabit halde tuttuğu, incelenen arşiv kayıtlarından anlaşılmaktadır.

Tetkik edilen dönem ile ilgili olarak arşivde, yukarıda ifade edildiği üzere Malatya livasına ait Mufassal Avarızhane Defterlerine rastlanılmamıştır. Bu sebepten sancakta bir avarızhanesinin kaç gerçek hane veya vergi mükellefinden oluştuğu ve her vergi mükellefi başına düşen nüzul akçesi miktarı tam olarak tespit edilememiş ise de bir iki arşiv kaydından bu hususta kanaat verici bir neticeye varılabilir. Bu kayıtların erken tarihlisi, daha önce başka bir vesile ile bahsi geçen ve nizamı bozulan Zülkadriye eyaletindeki avarızhanelerin yeniden tanzimi ile ilgili Mayıs 1623 tarihli fermandır. Bu fermanda diğer direktiflerin yanında kazalardaki her üç vergi mükellefinin bir avarızhane birimi kabul edilmesi de belirtilmiştir (AŞS, 170A: 293-294). Diğer bir vesika, inceleme döneminin son yıllarına tarihli ve Gerger kazasındaki mufassal avarızhanelerinin yeniden sayım ve tashihine ait bir maliye defteridir. Muhteviyatından kazanın

${ }^{11}$ Mehmet Genç tarafindan "hazineye ait gelirlerin mümkün mertebe yüksek düzeye çıkarmak ve ulaştı̆̆ düzeyin altına inmesini engellemek olarak" tanımlanan fiskalizm hakkında daha geniş bilgi için bkz. Genç, 2003: 64-67, 83-88. 
yaklaşık 435 vergi mükellefi, 185 avarızhane itibar edilmiştir (KK.d., 2757: 118). İkinci kaynaktaki verilerden bir avarızhanenin yaklaşı 2,4 vergi mükellefinden oluştuğu ortaya çıkmaktadır. Yine 1717 senesine ait bir şer'̂̂yye sicili kaydından anlaşıldığ kadarıyla Malatya kazasının mahallelerinde vergi veren reayanın 368 hanesi, mevkufat defterlerinde 97 ve 2 sülüs avarızhane kabul edilmiştir (MŞS, 2: 121; Karagöz, 2003: 143). Sicilin sunduğu bilgilerden de kazanın merkezinde bir avarızhanesinin yaklaşık 3,8 vergi mükellefinden oluştuğu ortaya çıkmaktadır. Tüm bu verilerin ortalaması alındığında Malatya livasında bir avarızhanenin yaklaşık üç gerçek hane veya vergi mükellefinden teşekkül ettiği rahatlıkla söylenebilir. Bu değeri, tüm liva için ihtiyatla, doğru kabul edersek Sancak'taki her vergi mükellefinin, diğer vergilerin yanında aşırı uç değerler dışında, yaklaşık 100-200 akçe nüzul bedeline ilaveten 10 akçe de mübaşir ücreti ödediği anlaşılır. 1067/1656-57 yılına mahsuben ve nakden istenen Malatya livasının sürsat zahiresi için maliye büroları tarafından tespit edilen rayice göre bir koyunun fiyatı 160 akçe, bir kıyye (okka) yani 1.282 gr. sadeyağın fiyat 30 akçe ve bir kıyye balın fiyatı ise 20 akçe olarak kaydedilmiştir (KK.d., 2624: 105). Gerçi hazinenin faydası gözetilerek merkezi idarece tespit edilen bu değerler, şehirde piyasa için belirlenen narh fiyatlarından oldukça yüksek tutulmuştur. Nitekim Malatya kadısı denetiminde bakkallar için tanzim edilen 27 Ekim 1657 tarihli bir narh kataloğuna göre tereyağının okkası 18 akçe, balın okkası 16 akçe, etin okkası 5 akçe olarak uygun görülmüştü (MŞS, 1: 196). Sicildeki 14 Haziran 1658 tarihli bir diğer narh listesine göre ise şehir merkezinde bir okka etin fiyatı 5 akçedir (MŞS, 1: 1; Karagöz, 2003: 252). Her iki kaynaktaki değerler göz önüne alınırsa şehirdeki halkın nüzul vergisi karşılığında ödediği miktarın günlük hayatında kullandığı emtia değeri ve günümüz ölçülerine dönüşümü hakkında bir fikir yürütülebilir. Mesela, bu verilere göre 1657 yılında Malatya kazasında bir vergi mükellefi, hazineye ödediği nüzul akçesi ile evine ortalama 6-12 okka tereyağı veya 7-13 okka bal veya 20-30 okka et alabilmekteydi ${ }^{12}$. Ancak avarızhane sayısının azaltıldığı dönemlerde veya bir avarızhanesinin daha fazla sayıda gerçek hane/vergi mükellefinden oluştuğu yerleşimlerde halk, bu değerin altında bir meblağ öderken avarız bedeli ile birlikte nüzul/nüzul bedeli, sürsat/sürsat bedeli ve bedel-i beldar gibi tekâlife muhatap olduğu vakitlerde ise çok daha fazla bir miktar ödemek zorunda kaldığını gözden uzak tutmamak gerekir. Ayrıca avarızhanesine dâhil tüm mükelleflerin eşit oranda değil tahammüllerine yani maddi imkân seviyelerine göre ednâ, evsât ve âlâ (alt, orta ve üst) gibi düzeylerde ve farklı oranlarda bu tekâlife iştirak ettirildiğini unutamamak lazımdır. Avarızhanelerine dâhil olan gerçek haneler veya vergi mükellefi mücerretler, kendilerine dağıtılan vergiyi aralarında paylaştıktan sonra belirtilen miktarı görevlilere öderlerdi (MŞS, 2: 12). Bazı zengin hayırseverler, hayır kazanmak maksadıyla nakit veya

12 Aynı değerleri, Malatya kazasında bazı mal ve hizmetler için düzenlenen narh fiyatlarıyla kıyaslamak için bkz. Karagöz, 2003: 249-253. 
gayrimenkullerinin gelirlerini, mahallede bu vergiyi ödemekte zorluk çeken avarız mükelleflerine yardım etmek amacıyla vakfederlerdi. Mahallenin sandığ 1 mesabesindeki bu vakıflara avarız vakfı denilirdi (İpşirli, 1991: 109; Sahillioğlu, 1991: 109). Avarız vakıfları hakkında önemli ve detaylı bilgiler sağlayan Malatya şer'̂̂yye sicillerinden, bu döneme ait olanlardan, sadece bir tanesi günümüze gelebilmiştir. Gerek bu sicilde gerekse de diğer arşiv belgelerinde Malatya kazasındaki avarız vakıfları hakkında herhangi bir bilgiye ulaşılamamıştır. Ancak bu dönemde komşu livalardan Ayntab ve Maraş'ta yaygın bulunan bu kurumların Malatya'da da var olabileceğini tahmin etmek güç değildir.

Elde edilen bilgilere göre 1624-1700 yılları arasında Malatya sancağındaki avarızhane/nüzulhane sayılarındaki değişim, 1.171 - 919,5 ve 1 rub arasında azalma yönünde olmuştur. Aynı zaman diliminde Malatya kazasında da 360 ile 270 ve $1 \mathrm{rub}$ avarızhanesi arasında yine aşağı yönlü bir farklılaşma meydana gelmiştir. Başka bir ifade ile 76 yıllık bir zaman diliminde liva genelinde yaklaşı $\% 22$, kaza sahasında ise \%25 civarında bir eksilme gerçekleşmiştir. Aynı dönemde Zülkadriye/Dulkadir eyaletinin diğer bir sancağ 1 olan Maraş'ta bu düşme $\% 50$ civarında gerçekleşmiştir (Arslan, 2014: 270) ${ }^{13}$. Yapılan tespit ve gözlemlere göre bu düşüş, dramatik bir nüfus azalmasından ziyade, aşiretlerin iskân durum/mahallerinin değişmesinden kaynaklı nüfus hareketliliğinden, yeni muafiyetlerin verilmesinden veya başka hizmetlere tayin edilmesinden ${ }^{14}$, bazı hanelerin mukataa haline getirilmesinden, zaman zaman ekonomik durumları iyice kötüleşen halkın merkeze yaptığı şikâyet ve sızlanmalar üzerine Padişah'ın emri ile hanelerinin sayılarında yapılan tenzilat ve tashihlerden kaynaklanmıştır. Aslında Merkezi hükûmetin, halkın üzerindeki ağır vergi yükünü hafifletmek adına avarızhanelerin sayısını, nüfus miktarına göre zamanla artırmayıp aksine çoğu kez indirimler yaptığı arşiv belgelerinde sık karşılaşılan bir vakıadır. Nitekim hükûmetin, 17. yüzyılın sonlarına doğru bölgedeki bazı konargöçer aşiretleri Çukurova, Rakka, Hama ve Humus gibi bölgelere zorunlu iskâna tabi tuttuğ ${ }^{15}$ ve halk üzerindeki ağır vergi yükünü hafifletmek adına avarızhanelerin sayısını zamanla artırmayıp aksine indirimler yaptı̆̆ 1 arşiv belgelerine de yansımıştır. Bu bağlamda, 1 Aralık 1656 tarihli bir sicil hüccetinde Malatya kazasının 317 avarızhanesinden 24 adet indirim yapılınca geriye kalan 293 adet

\footnotetext{
${ }^{13}$ Osmanlı Devleti’nde 1640-1718 yılları arsındaki avarızhane sayılarının genel dağılımı ve bu zaman dilimindeki yüzdelik değişimi için bkz. Mc Gowan, 1981b: 118-120.

${ }^{14}$ Nitekim 1100/1688-89, 1102/1690-91, 1104/1692-93, 1106/1694-95 ve 1108/1696-97 yıllarında Malatya kazasının avarızhaneleri Malatya menziline menzilci olarak tayin edildikleri için kendilerinden ayrıca nüzul bedeli talep edilmemiştir (KK.d., 2728: 65; MAD.d., 3265: 68; D.MKF.d., 27665: 6; D.MKF.d., 27708: 2-3; MAD.d., 3807: 41; MAD.d., 3829: 94-96)

${ }^{15} \mathrm{Bu}$ dönemde yapılan zorunlu iskânlar hakkında geniş bilgi için bkz. Halaçoğlu, 1991; Orhonlu, 1987; Orhonlu, 1963; Tatar, 2005; Çelikdemir, 2001.
} 
avarızhane üzerinden avarız ve nüzül bedelleri tahsil edilmiştir (MŞS, 1: 17). Benzer şekilde 1694 yılında Gerger kazasında bozulan avarızhane düzenini yeniden sağlamak için çıkarılan ferman gereği, Mevkufat Kalemi kâtiplerinden Ömer Halife marifetiyle yapılan yeni tahrirde daha önce 200 adet olan Kaza'nın avarızhane sayısı 185'e indirilmiştir (KK.d., 2757: 1-18). Bunun yanında, çoğunlukla vergi mükelleflerinin itirazlarını ve merhamet ricalarını bildiren arz/arz-1 mahzarları üzerine, zaman zaman hükümdarın fermanı ile karye ve mahallelerin avarızhanelerinden de daha küçük tenzilatlar yapılmaktaydı. Mesela, 1026/1617 tarihinde Kâhta kazasının bedel-i nüzul talep edilen 45 avarızhanesinden kaza kadısı Abdullah Efendi'nin arzı ve Sultan II. Osman'ın bu konuda sadır olan fermanı mucibince 10 adet indirim yapılınca halkın vergi yükü yaklaşık \%22 azaltılmış oldu. Aynı tarihlerde Erzurum valisi Davut Paşa ile Şure kaza kadısı İsa Efendi'nin ayrı ayrı arzları ve padişahın fermanı üzerine bu kazanın 170 nüzulhanesinden 30 hanelik (yaklaşık \%18) bir tenzilat yapılmıştır (D.MKF., 27423: 51-52). Sultan IV. Murad, Revan seferi esnasında uğradığ 1 Malatya'da, şehrin fakirulhal oldukları bildirilen Küçek mahallesinin 2 avarızhanesinin silinmesini ferman etti. Bunun üzerine 28 Kasım 1635 tarihinde kazanın avarızhaneleri 329'dan 327'ye tashih edilmiştir (D.MKF.d., 27445: 15657).

Esasen sefer zamanlarında ve hazinenin fazla miktarda paraya ihtiyaç duyduğu durumlarda bir bölgedeki avarızhanelerin sayısı arttırılabildiği gibi, Devletin mali yönden rahatladığı zamanlarda ise, bölge halkının feryat ve talepleri de dikkate alınarak, avarızhane adedinde indirimler yapılması sıklıkla karşılaşılan bir durumdu. Buna dikkat çekici bir örnek Sadrazam Amcazade Hüseyin Paşa'nın, Sultan II. Mustafa'nın emri ile reaya üzerindeki mali yükü hafifletmek adına ülke genelindeki sancakların avarızhanelerinde indirimler yapmak için 1697 yılında gerçekleştirdiği çalışmalardır. Bu çalışmalar kapsamında, Malatya livasının 954,5 ve 2 sülüs ve 0,5 rub avarıhanesinden yaklaşık 35 adet hane düşürülerek avarızhane sayıs 919,5 ve 2 sülüs ve 0,5 rub olarak tashih edilmiştir (MAD.d., 3807: 42; KK.d., 2766: 26; Özkan, 2006: 165).

1036/1626-27 y1lı için tanzim edilmiş bir Nüzulhane defterindeki kayda nazaran aslen 140 avarızhane olarak görünen Malatya'nın Şure kazasında yapılan yeni yoklamaya ait müfredat defterinde bunun sadece 80 adedinin mevcut olduğu, 60 tanesinin namevcut olduğu görülmektedir. Muhtemelen bu yıllarda emniyetin kalmadığı ve Celali elebaşları ile diğer eşkıyanın kol gezdiği bölgede emniyetini kaybeden halkın perakende olmasından ${ }^{16}$ ötürü yaklaşık \% $43^{\prime}$ lük bir kayıp söz konusudur. Buna rağmen Devlet, hazinenin de fazla zarara uğratılmaması adına, bu iki değer ortasında 94 avarızhane üzerinden bedel

${ }^{16} \mathrm{Bu}$ devrede bölgedeki asayiş olaylarını arşiv belgelerine göre inceleyen bir çalışma için bkz. Demirci ve Arslan, 2012. 
talebinde bulunmuştur (MAD.d., 3862: 79). Padişahın fermanı üzerine 1037/1627-28 tarihinde livanın diğer kazalarının avarızhane sayılarında da halkın menfaatine yönelik tenzillerle 1slahlar gerçekleştirilmiştir. Bu kapsamda Malatya kazasından 30, Gerger kazasından 15, Hisn-1 Mansur kazasından 20 avarızhane düşürülmüştür. Hatta bu indirimlerin deftere işlendiği yerde, çıkarılan avarızhanelerden talep olunmasın diye yetkililere emr-i şerif yazılması istenmiştir (MAD.d., 6634: 21). Keza 1073/1662-63 yılında kaza kadısının arzı ve zamanın Padişahının fermanı mucibince Malatya kazasının 283 ve 0,5 rub olan avarızhanesinden 7 tanesi silinmiştir (MAD.d., 3157: 51).

Sonuç olarak, Devlet, bahse konu devirde yaygınlaşan eşkıyalık faaliyetleri ve ağır vergiler yüzünden mali durumlarının zayıflaması üzerine yerini yurdunu terk eden reayadan dolayı, mükellef sayısındaki azalmayı da dikkate alarak liva/kazadaki avarızhane sayısını, artırmayıp bunlardan indirimler yapmıştır. Ayrıca vergi miktarını enflasyon oranında artırmak yerine, akçenin değeri bu süre zarfinda yüzde yüz düşmesine rağmen, alınan meblağı yarım yüzyıldan fazla süre boyunca sabit tutmuştur. Böylelikle halkın daha fazla perişan ve perakende olmasını da engellemiştir.

Osmanlı vergilendirme politikası oldukça esnekti. Şartlara, zamana ve içinde bulunulan vaziyete göre çok farklılaşan ve uyum sağlayan bir yapısı vardı. $\mathrm{Bu}$ tabiatı gereği Devlet, aynı sene içinde olmasına rağmen, avarız akçesi ve nüzul bedeli gibi nakdî vergileri, ülkenin tüm bölge veya sosyal gruplarından hatta aynı livadaki tüm kaza ve topluluklardan aynı oranda talep etmeyebilirdi. Bu vergileri, zaman zaman hangi kıstasa göre değiştiği çok da anlaşılmayan, farklı miktarlarda istediği olurdu. $\mathrm{Bu}$ değişkenliğin sebebi ilgili resmi belgelerde çoğu zaman herhangi bir şerh yer almamaktadır. Kısaca Osmanlı maliyecilerinin vergilendirmede, bilhassa avarız türü yükümlülüklerde, ekseriyetle uyguladığ 1 farklı oranlarda tarh ve tahsil olağandı. Muhtemelen Devlet'in o andaki ihtiyaçları, vergiye muhatap olan yükümlülerin o andaki/daimi iktisadi ve içtimai koşulları, bir takım şikâyet ve sızıltıları, başkaca tekâlife muhatap olup olmaması, coğrafi konumu itibariyle daha önceki y1l/zamanlarda başka bir yükümlülüğe fazla katkıda bulunması hatta yaşanan iklimsel gelişmeler gibi faktörler bu farklılığı meydana çıkarmaktaydı. Tetkik edilen dönem içinde bu duruma sıkça rastlanılmaktadır. Mesela, şark seferine çıkan ordunun ihtiyaçları için tahakkuk ettirilen ve nakden alınan 1036/1626-27 senesi nüzul akçesini, Anadolu eyaletindeki livalar avarızhane başına üç yüzer akçe olarak ödemişlerdir. Eş zamanlı olarak Karaman, Rum (Sivas), Maraş, Haleb, Şam-1 Şerif, Trablusşam, Rakka, Adana, Malatya, Ayntab, Diyarbekir, Erzurum, Karahisar-1 Şarki ve Trabzon vilayetlerine bağlı livalar ise avarızhane başına bu miktarın tam iki katı olan 600 akçe üzerinden ödemeye mecbur edilmişlerdir (MAD.d., 3862: 4-24, 68-90). Daha ilginci, bir y1l sonra yani 1037/1627-28 senesine mahsuben gerçekleşen nüzul salınımında yaşandı. Bu tarhiyata göre Maraş eyaletine bağlı 
Maraş livası kazalarında nüzulhane başına 7 kâmil kuruş (560 akçe), Malatya livasının Gerger kazasında 7 kuruş (560 akçe) diğer altı kazasında avarızhane başına 11,65 kuruş (932 akçe), Ayntab livası kazalarında ise her avarızhaneden 10 kuruş (800 akçe) nüzul bedeli alınmıştır (MAD.d., 6634: 19-23). Aynı sene aynı yükümlülük, aynı bölge hemen hemen aynı sosyo-ekonomik hayat ve coğrafya olmasına rağmen 13 kazanın bulunduğu küçük bir eyalette birbirinden faklı 3 tarife ortaya çıkmıştır. Farklılığın sebebi ise meçhuldür. Aynı yıl Karaman ve Rum eyaletlerindeki kazalarda nüzul bedeli hane başına 20; Erzurum eyaletinde 13 kazada 8, 7 kazada 10; Diyarbekir eyaletinde bazı kazalarda 17, bazılarında 20 kâmil kuruş üzerinden hesaplanmıştır (Güçer, 1964: 80).

Benzer bir durum, 1100/1688-89 senesinde Ayntab, Malatya ve Maraş livalarındaki kazaların reayasından avarızhane başına 600 akçe nüzul bedeli talep edilirken maktu' olarak toplanan Maraş Şarkiyan Yörükleri ve Mamalı taifelerinden aynı vergi için avarızhane başına 680 akçe istenmesiyle yaşanmışıtır (MAD.d., 3820: 37). Bunlar ve burada zikredilmeyen çok sayıdaki arşiv kaydı, adı geçen vergilerin ne denli değişken olduğunu, şartlara ve ihtiyaç durumuna göre nasıl farklılaştığını gösteriyor.

Belgelerin ifadesiyle Memalik-i mahrûsenin (Osmanlı'nın korunmuş memleketi) diğer livalarıyla kıyaslandığında, Malatya livasının ödediği nüzul bedeli miktarının, çoğu livanın ödediğinin altında olduğu görülmektedir. Nitekim Merkezi hükûmet, 1108/1696-97 senesi için Malatya livasından toplam 3.530 esedi kuruş nüzul akçesi istemiştir. Bu yekûna Malatya kazası avarızhaneleri menzil cihetine tayin edildikleri için dâhil edilmemiştir. Eğer onlar da sayılmış olsalardı yaklaşık 5.017 esedi kuruşluk bir nüzul bedelleri ortaya çıkmaktadır. Hükûmetin, eş zamanlı olarak ülkenin diğer bazı sancaklarından istediği nüzul bedeli miktarları ise Tablo 4'teki gibidir (D.MKF.d., 27776: 6) ${ }^{17}$.

${ }^{17}$ 1114/1702-03 yılına ait bir karşılaştırma için bkz. MAD.d., 3091: 18-21. 
Tablo 4. Bazı Livalardan Talep Edilen Nüzul Bedelleri (1108/1696-97 Y1lında)

\begin{tabular}{llll}
\hline Livanın adı & $\begin{array}{l}\text { Ödediği } \\
\text { (Esedi Kuruş) }\end{array}$ & Livanın adı & $\begin{array}{l}\text { Ödediği } \\
\text { (Esedi Kuruş) }\end{array}$ \\
\hline Maraş & 2.858 & Kütahya & 18.471 \\
Ayntab & 2.660 & Kastamonu & 11.615 \\
Saruhan & 18.321 & Gelibolu & 7143 \\
Trabzon & 3.248 & Hüdavendigar (Bursa) & 19.272 \\
Ankara & $7.472,5$ & Sultanönü (Eskişehir) & 2.457 \\
Sivas & 16.134 & Karesi (Balıkesir) & 11.608 \\
Adana & 2.307 & Karahisar-1 Sahib (Afyon) & 4.560 \\
Kengiri & $6.046,5$ & Hamid-ili (Isparta-Burdur) & 9.688 \\
Bolu & 14.044 & Niğbolu & 33.278 \\
Yanya & 13.403 & Üsküp & 7.011 \\
Aydın & 22.365 & Trrhala & $15.959,5$ \\
Selanik & 17.012 & Silistre & 23.548 \\
Haleb & $19.246,5$ & Adana & 2.307 \\
Karaman & $15.956,5$ & Erzurum & 3.944 \\
Diyarbekir & 12.324 & Alanya & 1.748 \\
\hline
\end{tabular}

Malatya sancağındaki vergi mükellefleri nüzul bedellerinin yanı sıra, aynen avarız bedelinde olduğu gibi, tahsildar memurun maaşı için de mübaşir maişeti adıyla belli bir meblağ ödüyorlardı. Belgelerde "mübaşiriye" şeklinde de geçen bu ücret, Merkezi hükûmet tarafindan 1054/1644-45 yılında avarızhane başına onar akçe (D.MKF.d., 27468: 68), 1060/1650 (AŞS, 21: 63) ve 1068/1657-58 (MŞS, 1: 172) senelerinde ise bu meblağın iki katı olan yirmişer akçe olarak tespit edilmiştir. 18. yüzyılın başlarına gelindiğinde bu meblağ, $\% 50$ artmış haliyle 30 akçe şeklinde talep edilmeye başlanacaktır. Burada da bir kıyaslama yapıldığında Malatya halkının diğer eyalet ve kazalardakilerle aynı miktarda mübaşiriye ödediği anlaşılmaktadır. Mesela, Saruhan ahalisi 1650 yılında 20 akçe (Uluçay, 1944: 51) vermiştir. Kayseri sancağı reayası da 1660 yılından 1688 yılına kadar standart olarak 30 akçe, 1689 yılında ise 50 akçe ödemeye mecbur edilmiştir (Selçuk, 2008:175). Aynı tarihlerde Maraş ve Ayntab livalarında da bu değerlerin uygulandığı görülmektedir (İE.ML. 18-1673; Arslan, 2014: 278; Koçak, 2010: 233).

İstanbul'dan Malatya kazalarındaki kadı ve diğer yetkililere gönderilen nüzul ile ilgili tüm emir ve hükümlerde avarızhane başına belirlenen miktar ile mübaşir için tespit edilen ücret dışında emir ve deftere aykırı olarak kimseden kitabiye, hüddamiye, sarrafiye ve mahkeme harcı vesaire isimler altında herhangi bir ücret veya tefavüt-i kuruş, kesr-i mizan ve kuruş tartmak gibi bahanelerle asla bir akçe ve bir habbenin alınmaması ve aldırılmaması hususunda kendileri sıkı sıkıya tembih ve ikaz hatta tehdit edilerek Devlet'in bu noktadaki hassasiyeti 
tekrarlanmıştır (MŞS, 1: 151, 168, 171; AŞS, 21: 63; A.DVNSMHM .d., 44: 154; A. DVNS MHM.d., 59: 13: 154; KK.d., 2576: 10; TS.MA.d., 10642: 1). Hatta Malatya kazasına ait bir Şer'iyye sicili kaydından anlaşıldığına göre 1657 senesi Malatya avarız ve nüzül bedellerini toplayan mübaşir Ali Çavuş, muhtemelen daha sonra aleyhinde bir şikâyet vukuunda kendisini savunmak için görevinin bitiminde Şer'î Mahkeme'de şahitlerin huzuruyla Malatya kadısından, halktan belirlenen miktarın dışında herhangi bir şey almadığına dair hüccet almıştır (MŞS, 1: 17).

Pâyitaht'tan taşra idarecilerine yollanan bazı emirnamelerde kuruş bulunan yerlerde verginin defter suretlerinde belirtilen miktarda kuruş olarak, olmayan yerlerde ise akçe üzerinden tahsil edilmesi emredilirdi. Ayrıca halktan alınan akçenin halisü'l-ayar akçe yani sağlam olması, ayarı düşük, züyuf, kızıl ve kırkık akçe olmaması, eğer reaya, vergisini kuruş ile ödemek isterse bunun esedi ve kâmil kuruş veya zolatanın akçe cinsinden yine fermanda belirtilen değerleri üzerinden alınması ifade edilirdi (MŞS, 1: 151). 29 Aralık 1658 tarihli bir ferman suretinde taşrada kuruş parasının fazla miktarda alınıp verildiği ve reayanın mirî malı tahsildarlarına vergilerinin kuruş üzerinden almaları için teklif yaptıkları belirtilmiştir. Emrin devamında mübaşirlerin kuruş bulunan yerde kuruş, akçe olan yerde de akçe alabilecekleri fakat bunu yaparken reaya ve hazineye gadredilmemesi ve tam kuruşun 90 akçe, esedi kuruşun 80 akçe, zolatanın 50 akçe hesabı ile alınması istenmiştir. Eğer akçe alınacaksa züyuf, kırkık ve kemayar (ayarı bozuk, noksan) akçelerin kabul edilmeyerek "halisü'l-ayar akçe" alınması vurgulanmıştır (MAD.d., 3857: 3). Bu tarihteki resmi rayice göre tam kuruş 88, esedi kuruş 78 ve zolata 38 akçe değerindeydi (Pamuk, 1992: 152) ve maliyenin tespit ettiği kurdan biraz düşüktü. Bu bir sehiv değil, bilinçli yapılan bir muamele idi. Günümüzde de geçerli olan bu tatbikat, yani Devlet’in dövizi satarken yüksek alırken düşük kurdan hesaplaması, Osmanlı döneminde de aynen uygulanırdı. Bundan dolayı anılan belgedeki kayıtlarda da görüldüğü üzere Devlet, vergi tahsil ederken kuru, hazinenin lehine olarak yüksek tutmuştur. Nüzul akçesini kuruş cinsinden bir para ile talep ve tahsil ettiğinde ise bu paraları tedavüldeki rayiçten daima 10 akçe eksiğine almaktaydı. Kayıtlarda "tefavüt-i hasene/kuruş" olarak geçen bu fark hazineye fazladan gelir olarak kaydedilmiştir. 1691 y1lına gelindiğinde ise piyasada en az 120 akçe bir esedi kuruş etmekteyken (Pamuk, 1992: 152) Osmanlı maliyesi, genel eğiliminin aksine, anılan tarihte Malatya livasında nüzul bedeline esas kuruş nev' ve ederini belirlerken 110 akçeyi bir esedi kuruş olarak değerlendirmiştir (MAD.d., 3265: 68). En az \%10 serbest piyasa kurunun altındaki bu tespit elbette ki hazinenin zararına, halkın yararına idi.

Aynî nüzulde olduğu üzere nüzul bedellerinin tevzi ve tahsilinde de asıl mesuliyet ve salahiyet Malatya sancağındaki kadı/naiplere aitti. Kendilerine nüzul ile ilgili gönderilen emirlerde kazalarına konulan meblağı reaya arasında 
adalet ve hakkaniyet üzere dağıtmaları; bu işe memur mübaşire yardım edilerek verginin el birliği ile toplanarak hâsıl olan nüzul malının keselendikten sonra mühürlenip görevli mübaşir ve itimat edilir adamları vasıtasıyla ordu-yı hümayuna veya Hazine-i Âmire'ye gönderilerek teslim etmeleri emredilirdi. Tüm bu işlerin özen ve süratle yerine getirilmesi ve bu işlerde vuku bulacak herhangi bir ihmal ve reayaya yapılacak bir zulmün şiddetle karşılık bulacağı da tekraren ifade edilirdi. (AŞS, 15: 22; AŞS, 18: 90-91)

17. yüzyılın ilk çeyreğinden itibaren neredeyse düzenli vergiler gibi her sene vergi mükelleflerine tarh ve tahakkuk ettirilen nüzulün, kahir ekseriyetle bedel olarak istendiği incelenen vesikalardan hareketle rahatlıkla ifade edilebilir. Toplanılan bu nakit, seferberlik halinde ve harp sahasının Sancağa yakın olduğu durumlarda umumiyetle ordu hazinesine, aksi durumlarda Hazine-i Hümayun/Hazine-i Âmire/Asitane-i Saadet hazinesine (yani merkez hazineye) teslim edilmiş ve seferin lojistiğinde kullanılmıştır ${ }^{18}$.

$\mathrm{Bu}$ çalışmada tekraren dile getirildiği üzere Malatya livasından tahakkuk ettirilen nüzul bedeli hâsılatının, Devlet tarafından ilk zamanlarda çoğunlukla sefer halindeki askerlerin mühimmatı için harcandığını Nüzul Tevzi Defterlerinin girişlerindeki başlıklardan veya hükümlerden, vilayet yetkililerine gönderilen emirlerden anlamak mümkündür. Bahsedilen resmi belgelerde nüzulün talep edilme gerekçeleri daima açık seçik izah edilir ve bu gelirin Devlet için önemi hep vurgulanırdı. Mesela, 1054/1644-45 yılı Malatya livası avarızının, Girit Adası üzerine düzenlenecek sefer mühimmatı için bedel-i nüzul olarak talep ve tahsil edilmesi Maliye tarafindan kararlaştırıldı. 3.531,5 kâmil kuruş (282.520 akçe) tutarındaki bu bedelin tahsili için Maraş livasını da deruhte eden Maraş eyaleti valisi Vezir Tekeli Mustafa Paşa'ya emir ve defter gönderilmiştir. Paşa da tahsil ettiği meblağı, Hazine-i Âmire'ye teslim etmiştir (D.MKF.d., 27467: 11; D.MKF.d., 27468: 67-68). Yine 1672 yılında IV. Mehmed'in Lehistan üzerine gerçekleştirdiği Kamaniçe seferi masrafları kapsamında 1083/1672-73 senesine mahsuben Malatya Sancağının yedi kazasındaki 967 ve 0,5 rub nüzulhanesinden 576.070 akçelik (bu tutarın 165.675 akçelik kısmı Malatya kazasına ait) nüzul bedeli tarh edildi. Bu meblağ, arpa emini Mustafa Efendi eliyle toplandıktan sonra tefavütüyle birlikte benzer biçimde Hazineye teslim edilmiş̧ir (KK.d., 2657: 51; İnbaş1, 2004: 346).

Özü itibariyle olağanüstü bir harp mükellefiyeti olan fakat bu dönemde hazine için daimi bir gelir kaynağı haline getirilen avarız gelirlerinden Malatya nüzul bedeli/akçesinin, merkezî hükûmet tarafından bazen çeşitli hizmet veya

\footnotetext{
${ }^{18}$ Bazı mehazlar için bkz. MAD.d., 3862: 79; D.MKF.d., 27445: 49: MAD.d., 3855: 47; D.MKF.d., 27468:68; MAD. d. 3157: 51; MAD.d., 3857: 23; MAD. d., 3838: 43; MAD. d. 6633, 11-12.
} 
masraflara havale edildiği de vesikalardan anlaşılmaktadır. Bu bağlamda 1044/1634-35 senesi için Malatya livası nüzul bedellerinden bakaya kalan 500,5 tam kuruş emr-i şerif üzerine kaza naibi Mevlana Hüseyin hücceti ile sefer hazırlıkları kapsamında Malatya livasında top arabaları için beygir iştirasında bulunan Mehmed Bey'e 27 Haziran 1634 tarihinde teslim edilmiştir (D.MKF.d., 27445: 49). Hakeza 1070/1659-60 senesi Malatya nüzul bedeli hâs1lının 3.717 akçesi 18 Nisan 1660 tarihinde bazı sipahilerin mevâciblerine yani maaşlarına havale edilmiştir (MAD.d., 3857: 23). Livanın 1109/1697-98 senesi nüzul bedelleri, Malatya menzilinin aynı senenin beygir ücretleri ve diğer masraflarına harcanmıştır (AE.SMST.II. 59-6181). Yine Padişahın yakın koruma ekibindeki silahtarlardan Mehmed İsmail'in maaşı, kendisine tahsis edilen Erzurum cizyesinden mümkün olmayınca, Malatya bedel-i nüzulünden Melek Ahmed Paşa adamı Mehmed Çelebi yediyle tahsil olunan paradan 22 Şubat 1652 tarihinde tesviye edilmiştir (İE.ML. 8-655). 11 Haziran 1661 tarihli bir tezkereden sancağın avarız ve bedel-i nüzul malı, Peksimet Emini Hacı Osman Ağa marifetiyle donanma leventleri, Dergâh-1 Âli yeniçerileri, cebecileri ve topçuları için mubayaa olunan peksimet masraflarına harcanmak üzere havale edildiği anlaşılmaktadır (AE.SMMD. IV. 90-10642).

17. yüzyılın ikinci yarısından itibaren artık olağanlaşan ve nakdileşen Malatya nüzul geliri, 1660'lı yılların ortalarından itibaren de bazen tek başına çoğunlukla da aynı livanın avarız akçeleri ${ }^{19}$ ve başka liva/kazaların avarız akçesi/nüzul bedelleri ile birlikte İstabl-1 Âmire'ye yani saraydaki has ahırın daimi masraflarına ocaklık olarak tayin edilmiştir. Nitekim 1078/1666-67 yılı için tarh edilen Malatya, Üsküp, Delvin, Drama, Gümülcine ve daha birkaç kazanın avarız akçesi ile nüzul bedelleri ve bunların tefavütlerinden hâsıl olan 12 milyon 117 bin 391 akçelik tutarın bu kurumun mühimmatı cihetine toplanması için 19 Nisan 1667 tarihinde Arpa Emini Süleyman Efendi'ye emr u defteri verilmiştir (MAD.d., 3836: 16, 47). İște bu tarihlerden 1690'l yılların başlarına kadar, ekseri arpa eminleri tarafından üstlenilerek tahsil edilen Malatya nüzül bedellerinin, sarayın has ahırlarının başka bir ifade ile Arpa Eminliği'nin masraflarına ocaklık olarak tayin edildiği arşiv vesikalarından anlaşılmaktadır. Mesela Arpa Emini Hasan Efendi uhdesinde yer alan Paşa livasına tabi Drama, Razlık, Tatarpazarı, Filibe ve diğer kazalar ile Malatya, Maraş ve diğer livaların 1106/1694-95 yılının avarız akçesi ve nüzul bedellerinden oluşan 7.500 kuruşluk (900.000 akçelik) bir tutar, 22 Mayıs 1697 tarihinde İstabl-1 Âmire mühimmatına harcanmıştır (AE.SMST.II. 118-12927). Yine adı geçen eminin üzerinde olup yukarıda sayılan

19 Malatya sancağının nüzul bedellerinin, avarız akçeleriyle ile beraber bahsedilen tarihten yüzyılın sonuna kadar daimi ve düzenli bir şekilde talep edilerek İstabl-1 Âmire giderlerine ocaklık olarak tahsis edilmesi hakkında bazı arşiv vesikaları için bkz. D.MKF.d., 27520: 45; D.MKF.d., 27600:5; D.MKF.d., 27613: 1; KK.d., 2688: 2, 30; MAD.d., 3807: 41-42; KK.d., 2657: 51. 
kaza ve livalara ait 1107/1693-94 senesi avarız ve nüzul bedelleriyle tefavütünün oluşturduğu 14.062,5 kuruşluk (1.678.500 akçelik) meblağ dahi bu kurumun masraflarına harcanmıştır (AE.SMST.II. 112-12183). Keza, yekûnu 24.147 esedi kuruş tutan Malatya ve Maraş livalarının 1104/1692-93 ve 1105/1693-94 tarihlerine mahsuben talep edilmiş olan avarız ve nüzul bedellerinden sadece 8.182 kuruşu teslim edilmiş, 15.965 kuruşu da bakaya düşmüştür. Kalan bakiyenin 5.000 kuruşu İstabl-1 Âmire'nin mühimmatına, 1.800 kuruş da cev (arpa) eminin maaşına havale edilmiştir (D.MKF.d., 27700: 4; D.MKF.d., 27714: 2). Bu zikredilen tarihlerin dişında, belgelerden tespit edilebildiği kadarıyla, en az 1082/1671-72, 1085/1674-75, 1086/1675-76, 1089/1678-79, 1090/1679-80, 1097/1685-86, 1098/1686-87, 1100/1688-89, 1101/1689-90, 1102/1690-91, 1104/1692-93, 1107/1695-96 ve 1108/1696-97 y1llarında Malatya livas1 kazalarındaki reaya üzerine salınan nüzul bedeli malı Sarayın has ahırının ve Arpa Eminliği' nin giderlerine tahsis edilmiştir ${ }^{20}$. Özgün ifadesiyle İstabl-1 Âmire'ye ocaklık olarak tayin edilmiştir.

1695 yılında yapılan Sakız seferinin ağırlıklarını taşımak için kiralanan arabaların ücretleri de 1104/1692-93 ve 1105/1693-94 yıllarına ait Malatya avarız ve nüzul bedellerinden karşılanmıştır (D.MKF 501/151; Sevinç, 2010: 63). 1100/1688-89 tarihinden 1108/1696-97 yılina kadar Malatya kazas1 nüzulhanelerinin ödedikleri bedeller, artan masraflarını karşılamak maksadıyla Malatya menzili gelirlerine ilhak edildiği üstte ifade edilmişti. Diğer kazalardaki nüzulhaneler nüzul akçelerini ödemeye devam ettiler (KK.d., 2762: 37 ; MAD 3807: 41; KK.d., 2728: 65). Yine 8 Haziran 1702 tarihli bir hüküm kaydına göre Malatya sancağı avarız ve nüzül bedellerinden 338 esedi kuruş ile 13 adet mısri para ve bir akçelik meblağ Malatya sancağında bulunan Hasan Çelebi menzilinin atlarının masraflarına havale edilmiştir (İE.ML. 66-6153). Bir süre sonra Malatya ile Maraş, Ayntab, Hamid-İli ve Filibe livalarına tabi kazaların 1115/1703-4 yılına ait avarız ve nüzul bedeli malından 74.285 ve 1,5 rub esedi kuruş tekrar has ahırın giderlerine kullanılmıştır (MAD.d., 16009: 15).

Malatyalı ahali nüzul ödediği aynı senede bazen Devlet'in ihtiyacına göre başka olağanüstü yükümlülüklere de maruz kalmaktaydı. Mesela İstanbul hükûmeti, şark seferi vesileyle 1036/1626-27 senesinde hane başı altı yüzer akçeden toplam 657.600 akçe nüzul bedeli istediği Malatya kazalarının 1.142 avarızhanesinden beher hane yüz yirmişer akçeden toplam 137.040 akçe de bedel-i beldar istemiştir (MAD.d., 3862: 80, 95). 1038/1628-29 tarihinde

${ }^{20}$ Mehazları için bkz. MAD.d., 2790: 51: D.MKF.d., 27520: 45; D.MKF.d., 27564: 2; D.MKF.d., 27600: 6, 22; BAO, D.MKF.d., 27613: 1, 8; KK.d., 2728: 65; MAD.d., 3167: 77; MAD.d., 9480: 82; D.MKF.d., 27708: 2-3; MAD.d., 3265: 68; D.MFK.d., 27665: 6; AE.SMST.II. 24-2355; MAD.d., 3807: 41; KK.d., 2662: 46; KK.d., 2688: 2, 20-21. 
Sancak'tan 1.627.200 akçe (her hane 1.600 akçe ödemişti) nüzul bedeline ilaveten 392.800 akçe de sürsat bedeli talep edince halkın sadece bu iki kalemdeki vergi yükü 2.020.000 akçeyi bulmuştur (MAD.d., 6633: 45-46). Yüzyılın sonuna ait diğer bir örnekte Malatya halk1, 1100/1689-90 yılında hem 410.400 akçelik (3.731 esedi kuruş) nüzul bedeli hem 477.290 akçelik (4.339 esedi kuruş) sürsat bedeli hem de 960.250 akçelik $(8.729,5$ esedi kuruş) belderan bedeli ödemek zorunda bırakılmıştır (MAD.d., 3888: 4, 7; KK.d., 2728: 65). Toplam yükleri ise sadece bu üç kalemde 1 milyon 847 bin 940 akçe (16.800 esedi kuruş) tutmaktaydı.

Osmanlı Devleti'nde hububat ve onlar üzerinden alınan vergiler konusunda değerli çalışmalar yapan L. Güçer, arşiv kayıtlarından bazı kanıtlar sunarak Osmanlı Merkezi hükûmetinin avarız akçesi ile nüzul mükellefiyetini tedahül ettirmediğini yani her iki vergiyi birlikte aynı senede talep etmediğini ileri sürmüştür. Hatta Osmanlı maliyesi tarafından, olağanüstü bir vergi olan avarız akçesinin her yıl düzenli olarak tahsil edilen bir vergiye dönüştürülmesinden ve bir takım hizmetlerin devamlı masrafı (ocaklık) olarak tahsis edilmesinden sonra dahi, avarız akçesi ile nüzulün birlikte alınmamasına özen gösterildiğini, ifade etmiştir (Güçer, 1964: 92). Güçer'in bu tespitini, bizim de karşılaştığımız birkaç örnek desteklemektedir. Mesela Mevkufat kalemine ait 1054/1644-45 senesi Tevziat Defteri'ndeki kayıtlara göre o yıla ait Malatya livası avarıları, sefer mühimmatı için nüzül bedeli olarak tarh edilmiştir (D.MKF.d., 27468: 68). Defterin "Defter-i haneha-i avarı-1 kaza-i mezkurin bera-yı bedel-i nüzul berayı Sefer-i Hümayun fi sene 1054" tarzındaki başlı̆̆ından halkın bu seneye ait avarız mükellefiyeti yerine nüzul bedeli ödeyeceği gayet sarihtir. Zaten kendilerinden o sene için ayrıca avarız akçesi talep edildiğine dair herhangi bir emareye rastlanmamıştır. 17. yüzyılın ilk yarısında genel teamül böyle olmakla beraber çalışma dönemi içerisinde, bunun kesin bir kural olmadığını gösteren onlarca tatbikat ve yüzlerce kayıt bulunmaktadır. Osmanlı Devleti, batı sınırlarında yüzyılın ortalarında başlayıp hususan sonlarındaki Viyana faciasından sonra yarım düzine hasmılla giriştiği veya mecbur kaldığı uzun soluklu savaşlar ile baş etmek zorunda kalmıştır. Onun bu mücadelesinde halka daha fazla müracaat ettiğini, memleketin her köşesinde olduğu gibi Malatya sancağındaki reayadan da aynı sene içerisinde hem avarız akçesini, hem nüzul bedelini, hem sürsat bedelini, bazen de bunlara ek olarak beldar bedeli gibi birkaç tekâlif-i şâkkayı birlikte talep ettiğini gösteren onlarca kayda rastlanmıştır. Bunun en somut delillerinden biri de bazı Tevziat Defterlerinde aynı senenin avarızhane ve nüzülhane kayıtlarının beraber tutulmasıdır ${ }^{21}$. Önceleri bir araya nadir gelen iki arkadaş olan avarız ve nüzul, esasen araştırmaya konu olan yüzyılın tam da ortalarında artık ayrılmaz iki ikiz kardeş olmuşlardır. Örneğin, Malatya halkı,

${ }^{21}$ Örnekler için bkz. D.MKF.d., 27665; D.MKF.d., 27776; D.MKF.d., 27827; D.MKF. d., 27842; D.MKF.d., 27600; KK.d., 2688; MAD.d., 3067; MAD.d., 3748. 
1065/ 1654-55 senesinde hazineye hem avarızhanesi başına dört yüzer akçeden (toplam 400.800 akçe) avarız bedeli, hem de nüzulhane başına üç yüzer akçeden (toplam 300.200 akçe) bedel-i nüzul vergisini ödemiştir. İstanbul ağası Mustafa Ağa'nın deruhte ettiği, bu her iki verginin hâsılı, kendi mübaşir maaşı hariç, 700.900 akçe tutmaktaydı (KK.d., 2621: 22, 55; KK.d., 2623: 43.). Aynı minval üzere yukarıda bahsedildiği gibi 1670 yılından sonra Malatya nüzul bedelleri ile avarız akçeleri birlikte sürekli ve düzenli bir şekilde İstabl-1 Âmire için ocaklık olarak tayin edilmiştir. Nitekim şehirdeki mükellefler, 1090/1679-80 tarihinde bu seneye mahsuben 384.450 akçesi avarız, 576.080 akçesi nüzul bedeli olmak üzere toplam 960.130 akçeyi saray ahırlarının gideri için vermişlerdir (D.MKF.d., 27564: 2). Hatta dönemin sonlarında, şartların vahametinden ötürü bu tedahül durumu artık sıradanlaşmıştı. Örneğin, Osmanlı Maliyesi, felaket senelerine denk gelen 1104/1692-93 y1lında sancaktaki kazaların toplam 960 ve 0,5 rub olan avarızhanelerine 3.495 esedi kuruşluk (384.450 akçe) avarız akçesinin yanı sıra 684 adet nüzulhanesine de 3.731 esedi kuruşluk (410.410 akçe) nüzul bedeli olarak toplam 7.226 kuruş (794.860 akçe) tarh etmiştir. Sancağın kazalarındaki her bir avarızhane, avarız akçesi için dört yüzer akçe, nüzul bedeli için de altı yüzer akçenin yanında mübaşir ücretleri için de seksener akçe ödemek zorunda bırakılmıştır. Mükellefler, iki sene önce de aynı şekilde böyle kombine bir tekâlif ile yüz yüze bırakılmışlardı (D.MKF.d., 27665:7; D.MFK.d., 27708: 2-3; MAD.d., 3260: 75). Bu vergilere muhatap mal mülk sahibi reaya, 1110/1698-99 senesinde her iki yükümlülük ve tefavütü için toplam 8.431 esedi kuruşluk (927.410 akçe) bir meblağ ödemiştir (D.MKF.d., 27782: 4-5). Daha pek çok misali bu makamda zikretmek mümkün ise de çalışmanın hacminin uzamaması için kısa keserek sadece 17. yüzyılın ikinci yarısında nüzul ile avarızın Malatya kazalarında aynı zamanda tarh ve tahsil edildiği yıllar ve kaynakları verildi. Tespit edildiği kadarıyla 1064/1653-54, 1065/1654-55, 1074/1663-64, 1075/1664-65, 1078/1667-68, 1082/1671-72, 1083/1672-73, 1086/1675-76, 1089/1678-79, 1090/1679-80, 1097/1685-86, 1098/1686-87, 1102/1690-91, 1104/1692-93, 1106/1694-95, 1108/1696-97; 1109/1697-98, 1110/1698-99, 1112/1700-01, 1113/1701-02 ve 1114/1702-03 yıllarında Malatya livasındaki vergi mükelleflerine avarız ve nüzul birlikte salınmıştı ${ }^{22}$.

${ }^{22}$ Mehazlar için bkz. KK.d., 2621: 21, 55; KK.d., 2623; 43-44; KK.d., 2627: 46; KK.d., 2657: 51; KK.d., 2665: 22; KK.d., 2668: 20-21; KK.d., 2688: 2; MAD.d., 2790: 51; MAD.d., 2412: 39; MAD.d., 2989: 51; MAD.d., 3067: 20; MAD.d., 3091: 11, 21; MAD.d., 3748: 9, 15; MAD.d., 3354: 7; MAD.d., 3807: 41; MAD.d., 3829: 94-96; MAD.d., 3836: 47; MAD.d., 3856: 44; D.MKF.d., 27564; 2; D.MKF.d., 27600: 6, 22; D.MKF.d., 27613:1, 8; D.MKF.d., 27665: 6; D.MKF.d., 27708: 2-3; D.MFK.d., 27776: 6; D.MKF.d., 27842: 4; D.MKF.d., 27827: 13, 24; D.MKF.d., 27853: 29, 41; D.MKF.d., 27782: 3-5. 
Uzun süredir süreklilik kazanıp ağırlaşan bu iki yükümlülüğün altında bunalan Malatya ahalisi için bu durumdan daha ağırı ise 1683 Viyana bozgunundan sonra, bazen aynı yıl içinde bunlara ilaveten sürsat mükellefiyeti ile de muhatap olmasıydı. Çünkü bu üç verginin birlikte halka teklif edildiğini birçok arşiv vesikası açıkça göstermektedir. Nitekim, Malatya livasında vergi ödeyen vatandaşlar, 1100/1688-89 yılında nüzül bedeli için 3.731, avarız akçesi için 3.495 ve sürsat bedeli için de 4.339 esedi kuruş olmak üzere toplam 11.565 esedi kuruş (1.272.150 akçe) tutarında avarız-1 divaniye vergisi ödemişlerdir (D.MKF.d., 27635: 1; KK.d., 2728: 65; MAD.d., 3167: 54, 77). Bir İcmal Muhasebe Defterine göre 1110/1698-99'da Osmanlı Maliye Yönetimi, yaklaşı 920 avarızhane/nüzulhanesi olan Malatya kazalarından bu sene içinde avarızhane başına dört yüzer akçeden olmak üzere 368.517 akçe (3.350 ve 1 rub esedi kuruş) avarız akçesi; beher nüzulhanesi altı yüzer akçeden toplam 552.175 akçe (5.019,5 rub 1 kuruş-1 esedi) nüzul bedeli ve 5.500 esedi kuruş da sürsat bedeli talep etmişti. Ahali ayrıca avarız akçesinin yanında ekstradan 61 kuruş tefavüt kuruş ile karşı karşıya kalınca o sene toplam 13.975,5 ve 1 rub esedi kuruş (1.537.403 akçe) ödemiştir (D.MKF.d., 27782: 4-5).

Ancak hükûmet İstanbul'da ne tarh ettirirse ettirsin, halkın bu vergileri tam ve zamanında ödeyemediği ve kısm-1 ekserisinin reaya zimmetinde kaldığ 1 yine Bakaya Defterlerinden anlaşılmaktadır (D.MKF.d., 27652: 6). Mesela yekûnu 24.147 esedi kuruş olan Malatya ve Maraş livalarının 1104 ve 1105 senelerine ait avarız ve nüzul bedellerinden sadece 8.182 kuruşu teslim edilmiş, 15.965 kuruşu da bakaya kalmıştı (D.MKF.d., 27700: 4; D.MKF.d., 27714: 2). Bu bahis ile alakalı olarak da çok misaller verilebilir. Ancak bir kısmı üst satırlarda başka vesileler ile geçtiği için tekrarlanmamıştır. Halkın sıkça şikâyetine ve sızlanmasına sebebiyet veren bu ağır tekâlifi yapmaya Devleti iten asıl sebebin savaş ekonomisi olduğu düşünülmektedir ${ }^{23}$.

\section{SONUÇ}

$\mathrm{Bu}$ çalışma Osmanlı Devleti'nin, 17. yüzyılda, Osmanlı tarihi üzerine çalışanlarca belki de en çok farklı yorumlanan ve nitelenen bir döneminde, ülkenin mütevazı bir sancağı olan Malatya'da nüzul yükümlülügünün tarh, tevzi, tahsil ve teslim aşamalarından teşekkül eden sürecini imkânlar ölçüsünde tetkik etmeyi amaçlamıştı. Kaynak olarak Devlet Arşivleri Başkanlığı bünyesindeki Osmanlı Arşivi'nin çeşitli fonlarında kayıtlı onlarca İcmal Avarız veya Mevkufat Defterinin yanı sıra çok sayıda vesika kullanılmışıtır. Çalışmanın arşiv araştırması sürecinde mevzubahis dönem için Malatya livasına ait ve bu tür konularda daha

${ }^{23} \mathrm{Bu}$ konu hakkında detaylı bilgi için savaş ile ekonomi arasındaki ilişkiyi ve savaşın ülke ekonomisine etkilerini 17-18. yüzy1l Osmanlı örneği üzerinden güzel bir üslup ile anlatan şu esere bkz. Genç, 2003: 210-225. 
sağlıklı, daha teferruatlı bilgiler sunan Mufassal Avarız Defterleri ve Malatya kazası Şer'îyye Mahkemesi'nde tutulan sicillere rastlanmamıştır. Bu durum, işimizi biraz zorlaştırıp çalışmamızı kısıtlasa da tespit ve temin edilen diğer kayıtlarla olabildiğince verimli bir çalışma yapmaya çalıştık.

Esasen genel kanının aksine dikkatle incelendiğinde ve değerlendirildiğinde İcmal Avarız Defterlerinden de nüzulün mahiyeti/kimliği, zaman içindeki seyri, tarh-tahsil vetiresindeki işleyişi, bu vetirede meydana gelen kimi zaman radikal kimi zaman da yavaş ancak istikralı bir tarzda arızilikten daimiliğe, aynîlikten nakdiliğe doğru olan değişim/dönüşümü gözlemlenebilir. Yine mübaşirlerin kimlikleri, o görevi nasıl ve hangi ilişkileri sayesinde ne gibi şartlarla deruhte ettikleri, yüklendikleri nüzul malını reayadan toplamadan hazineye teslim edinceye kadarki süreçte yaşadıkları zorlukları aynı kayıtlardan izlemek pekâlâ mümkündür. Bu defterlerde ehemmiyetsiz gibi görünen bir takım muamele kayıt ve derkenarlarından vergiye muhatap kişi/toplulukların bütün bu süreçten nasıl etkilendikleri ve ona karşı gösterdikleri tepkileri, yük çekilmez hale gelindiğinde açığa vurdukları sızıltıları/feryatları, bir şeyler yapmak adına nasıl harekete geçtikleri ve seslerini Merkeze duyurabilmek için gösterdikleri çabaları hissedilebilir, görülebilir. Ayrıca bu bilgi kırıntılarından taşradan mütemadiyen yükselen vaveylalara ve terahhum ricalarına Sultan ve maiyetindeki idare adamlarının nasıl bir cevap verdikleri sezilebilir. İşte bu araştırmada tüm bu boyutlara değinilmeye çalışılmış, çeşitli malî-idari-kazaî-askeri amaçlar için tanzim edilen bu resmi kayıtlardaki dağınık bilgiler anlamlandırılınca önemli sonuç ve veriler elde edilmiştir.

Metni fazla uzatmamak adına burada bu verilerle ilgili olarak kısaca şunlar söylenebilir. Çalışılan dönem boyunca Maraş eyaletine dâhil olan Malatya sancağ 1 vergi çevresi olarak Malatya, Kâhta, Şure, Taşabad, Behisni, Gerger ve Hısn-1 Mansur-Samsad-Bezeki kazalarından oluşuyordu. Osmanlı'nın Şark seferleri ve asi paşalar üzerine yapılan harekâtlarda Livadaki kazalarda nüzul zahiresi genel olarak aynen alınmıştır. Batı tarafına yapılan seferlerde ve sulh zamanlarında ise nakit olarak tarh ve tahsil edilmiştir. Nüzulün adalet ve hakkaniyet üzere tevzi, tahsili ve emredilen yere veya kuruma tesliminde en büyük mesuliyet ve salahiyet kadıda olmakla beraber tüm yerel idareci ve ileri gelenler de işe koşulurdu. Aynî nüzulde genel olarak dörtte biri un olmak üzere arpa ve un/buğday talep edilirdi. Malatya kazalarında yaklaşık 3-4 gerçek vergi mükellefinden meydana geldiği tespit edilen itibari avarızhane/nüzulhane birimleri üzerinden işler yürütülmüştür. Birim başına istenilen zahire miktarı çok değişken olmakla beraber dönem boyunca avarızhane başına 1,5 kileden 24 kileye kadar farklı miktarlarda alınmıştır.

17. yüzyılın ilk çeyreğinden sonra nüzul vergisi, daimilik vasfiyla birlikte nakdîlik özelliğini de pekiştirmeye başlamıştır. Hemen hemen her yıl tarh ve 
tahakkuk ettirildiği anlaşılmaktadır. Halk, özellikle buhranlı dönemlerde iki üç kez nüzul bedelini avarızhane başına 1.600 akçeye (20 kâmil kuruş) gibi yüksek miktarda öderken rahatlama dönemlerinde 1650'li yılların ortasına kadar 300400, bu tarihten itibaren ise 500-600 akçe gibi standart bir meblağ üzerinden ödemiştir. Vatandaşlar ayrıca avarızhane başına 20-30 akçe de mübaşir ücreti vermekteydiler. Bu vergi dönem ortalarında sabitlenmiştir. Ancak istenen miktar genel kanının aksine tahammül gücü açısından, akçenin değer kaybı ve uzun süre bu meblağın değişmemiş olması göz önüne alındığında, normal sınırlar içindedir.

Yapılan tespitlere göre avarızhane sayıları 1624-1700 yılları arasında Malatya livasında yaklaşık 1.171-920 aralığında, kazasında ise 360-270 aralığında değişmiştir. 76 yıllık bir zaman diliminde liva genelinde yaklaşı \%22, kaza sahasında ise $\% 25$ civarında bir değişme gerçekleşmiştir. Bu aşağ 1 yönlü düşüşün, dramatik bir nüfus azalmasından ziyade, aşiretlerin iskân durum/ mahallerinin değişmesinden kaynaklı nüfus hareketliliğinden, yeni muafiyetlerin verilmesinden veya başka hizmetlere tayin edilmesinden, bazı hanelerin mukataa haline getirilmesinden, zaman zaman ekonomik durumları iyice kötüleşen halkın avarızhanelerinin sayılarında Padişah'ın emri ile yapılan tenzilat ve tashihlerden kaynaklandığı tespit edilmiştir.

Anılan dönemde Malatya reayasından bir iki istisna dışında nüzul ile birlikte ekseriya avarız akçesi ve sürsat bedeli talep edilirken ihtiyaç halinde bunlara ilaveten beldar bedeli de istenilmiştir. Ancak bu araştırmada Devlet'in istikrarlı ve şartlara göre esnetilen bir vergi politikası uygulayarak zaman zaman ağır mali yükümlülüklerin altında ezilen ahaliye Sultan'ın iradesi üzerine ya istenilen meblağın miktarında veya nüzulhane sayılarında indirimler yaparak bir nevi vergi affı getirdiği gözlemlenmiştir. Malatya nüzul malı çoğunlukla sefer halindeki ordunun ihtiyaçlarına nadiren yeniçeri ve değişik personelin mevâciblerine, menzil ihtiyaçlarına ve mubayaa masraflarına harcanırken 1670 yılından yüzyılın sonuna kadar da sarayın has ahırlarına yani İstabl-1 amireye ocaklık tayin edilmiştir.

\section{KAYNAKÇA}

\section{Arşiv Kaynakları}

\section{Cumhurbaşkanlığı Devlet Arşivleri Başkanlığı Osmanlı Arşivi (BOA)}

Ali Emiri (A.E.): Sultan II. Mustafa (AE..SMST.II.) Nu: 59-6181, 112-12183, 118-12927, 24-2355.

Ali Emiri (A.E.): Sultan IV. Murad (AE.SMMD.IV.) Nu: 6-576, 90-10642. 
Ali Emiri (A.E.): Sultan İbrahim (AE.SİBR) Nu: 1-42.

Bâb-1 Âsafi Mühimme Defterleri (A.DVNSMHM.d.), Nu. 3, 32, 44, 53, 59.

Bâb-1 Defteri Mevkufat Defterleri (D.MKF.d.) Nu: 27423, 27445, 27467, 27468, 27520, 27564, 27600, 27613, 27635, 27652, 27665, 27700, 27708, 27714, 27776, 27782, 27827, 27842, 27853.

Bâb-1 Defteri Mevkufat Kalemi (D.MKF): Nu. 501-151; 15-56.

Cevdet Tasnifi (C): Maliye (C..ML.) Nu. 378-15521.

İbnülemin (İE.) Tasnifi Maliye (İE.ML.) Nu. 8-655, 18-1673, 66-6153.

Kamil Kepeci Tasnifi (KK.d.) Nu. 2553, 2576, 2613, 2618, 2621, 2623, 2624, 2627, 2635, 2651, 2657, 2659, 2662, 2665, 2668, 2688, 2728, 2757, 2766, 2762, 2775.

Maliyeden Müdevver Defterler (MAD.d.) Nu. 457, 2412, 2790, 2989, 3028, 3048, 3067, 3091, 3157, 3167, 3198,3260, 3265, 3354, 3471, 3748, 3807, 3809, 3820, 3829, 3836, 3838, 3853, 3855, 3856, 3857, 3862, 3888, 4347, 6633, 6634, 7104, 9480, 16009.

Topkapı Sarayı Müzesi Arşivi Defterleri (TS.MA.d.) Nu: 10642.

Topkapı Sarayı Müzesi Arşivi Evrakı (TS.MA.e.) Nu: 551/94.

Ayntab Şer’iyye Sicili (AŞS), Nu: 15, 18, 121, 170A.

Malatya Şer'iyye Sicili (MŞS), Nu. 1, 2.

\section{Telif Eserler}

1530 Tarihli Malatya, Behisni, Gerger, Kâhta, Hısn-1 Mansur-1 Mansur, Divriği ve Darende Kazaları Vakıf ve Mülk Defteri. (2007). (Yay. Haz. Gülsoy, E. \& Taştemir, M.), Türk Tarih Kurumu Yay.

Arslan, H. (2014). 17. Yüzyılda Maraş Sancağı (Siyasi, İdari, İktisadi ve İçtimai Tarihi). Dulkadiroğlu Belediyesi Yay.

Barkan, Ö. L. (1993). Avarız. İslam Ansiklopedisi içinde (cilt 2, ss. 13-19). Milli Eğitim Yay.

Cezar, M. (1965). Osmanlı Tarihinde Levendler. İstanbul Güzel Sanatlar Akademisi Yay. 
Çakar, E. (2006). 17. Yüzyılda Haleb Eyaleti ve Türkmenleri, Firat Üniversitesi Orta Doğu Araştırmaları Merkezi Yay.

Çelikdemir, M. (2001). Osmanlı Döneminde Aşiretlerin Rakka'ya İskânı (16901840). [Yayımlanmamış Doktora Tezi]. Fırat Üniversitesi.

Darling, L.T. (1996). Revenue-Raising and Legitimacy. Tax Collection and Financial Administration in the Ottoman Empire, 1560-1660. Brill.

Demirci, S. \& Arslan, H. (2012). Osmanlı Türkiyesi’nde Eşkıya, Devlet ve Siyaset Maraş Eyâleti Örneği (1590-1750). Yalın Yay.

Emecen, M.F. (1989). XVI. Asırda Manisa Kazası. Türk Tarih Kurumu Yay.

Genç, M. (2003). Osmanlı Imparatorluğu'nda Devlet ve Ekonomi, Ötüken Yay.

Göğebakan, İ. (2002). XVI. Yüzyılda Malatya Kazası (1516-1560). Malatya Belediyesi Yay.

Güçer, L. (1964). XVI-XVII Asırlarda Osmanlı Imparatorluğu'nda Hububat Meselesi ve Hububattan Alinan Vergiler. İstanbul Üniversitesi Yay.

Halaçoğlu, Y. (1991). XVIII. Yüzyılda Osmanlı İmparatorluğu'nun İskân Siyaseti ve Aşiretlerin Yerleştirilmesi. Türk Tarih Kurumu Yay.

Hinz, W. (1990) İslam'da Ölçü Sistemleri, (Çev. Sevim Acar). Marmara Üniversitesi Fen-Edebiyat Fakültesi Yay.

İnalc1k, H. (1980). Military and Fiscal Transformation in the Ottoman Empire, 1600-1700. Archivum Ottomanicum, 6, 283-337.

İnalcık, H. (2017). Osmanlı İmparatorluğu'nun Ekonomik ve Sosyal Tarihi-I 1300-1600. H. Berktay (Çev.). Türkiye İş Bankası Kültür Yay.

İnbaş1, M. (2004). Ukrayna'da Osmanlılar Kamaniçe Seferi ve Organizasyonu. Yeditepe yay.

İpşirli, M. (1991). Avarız Vakfi. Diyanet İslam Ansiklopedisi (DİA) içinde (1. Bask1. Cilt 4, 109). Türkiye Diyanet Vakfı Yay.

İşbilir, Ö. (1996). XVII. Yüzyıl Başlarında Şark Seferlerinin İaşse, İkmâl ve Lojistik Meseleleri. [Yayımlanmamış Doktora Tezi]. İstanbul Üniversitesi.

İşbilir, Ö. (2002). Osmanlı Ordularının İâşe ve İkmâli: I. Ahmet Devri İran Seferleri Örneği, içinde G. Eren (Edit.), Türkler, X, (ss. 151-163). Yeni Türkiye Yay. 
İşbilir, Ö. (2007). Nüzul. Diyanet İslam Ansiklopedisi (DİA) içinde (1. Baskı. Cilt 33, s. 311-312). Türkiye Diyanet Vakfi Yay.

Karagöz, M. (2003). XVII. ve XVIII. Asırlarda Malatya Kazası (1650-1750). Karizma Yay.

Koçak, Z. (2010). Ayntâb Şehri'nin Sosyal ve Ekonomik Yaplsı (1600-1650). [Yayımlanmamış Doktora Tezi]. Atatürk Üniversitesi.

Küçük, L. (2007). Osmanlı Vergi Hukukunda Avarı Kavramı ve Avarızın İdaredeki Rolü. [Yayımlanmamış Doktora Tezi]. Ankara Üniversitesi.

Mc Gowan, B. (1981a). Osmanlı Avarız -Nüzül Teşekkülü 1600-1830. İçinde VII. Türk Tarih Kongresi (Ankara 11-15 Ekim 1976) Kongreye Sunulan Bildiriler, II, (ss. 1327-1331). Türk Tarih Kurumu Yay.

Mc Gowan, B. (1981b). Economic Life in Ottoman Europe: Taxation, Trade and Struggle for Land, 1600-1800. Cambridge.

Orhonlu, C. (1963). Osmanlı Imparatorluğu'nda Aşiretleri İskân Teşebbüsü (1691-1696). İstanbul Üniversitesi Yay.

Orhonlu, C. (1987). Osmanlı İmparatorluğu’nda Aşiretlerin İskânı. Eren Yay.

Özel, O. (2000). Avârız ve Cizye Defterleri. İçinde Ş. Pamuk (Edit.), Osmanlı'da Bilgi ve İstatistik, (ss. 35-50). Devlet İstatistik Enstitüsü Yay.

Özkan, S. H. (2006). Amcazâde Hüseyin Paşa'nın Hayatı ve Faaliyetleri (16441702). [Yayımlanmamış Yüksek Lisans Tezi]. Süleyman Demirel Üniversitesi.

Özlü, Z. (2015). Cenûbda Bir Şehr-i Medeniyet: Behisni (Bethesna-Besni). Gaziantep Üniversitesi Basımevi.

Pakalın, M. Z. (1983). Osmanlı Tarih Deyimleri ve Terimleri Sözlüğü, I-III. Milli Eğitim Bakanlığı Yay.

Pamuk, Ş. (1999). Osmanlı Imparatorluğunda Paranın Tarihi. Tarih Vakfı Yurt Yay.

Polat, S. (2015). IV. Murat'ın Revan Seferi Organizasyonu ve Stratejisi. Genelkurmay Askeri Tarih ve Stratejik Etüt (ATASE) Daire Başkanlığı Yay. 
Polat, S. (2018). Osmanlı Devleti’nde Nüzul Vergisinin Teşkili ve Gelişimi: XVI-XVII. Yüzyıllarda Osmanlı Ekonomisini Nüzul Vergisi Üzerinden Değerlendirmek. Belleten, LXXXII (295), 829-862. doi:10.37879/ belleten.2018.829

Sahillioğlu, H. (2004). Avarız. Diyanet İslam Ansiklopedisi (DİA) içinde (1. Baskı. Cilt 4, ss. 108-109). Türkiye Diyanet Vakfı Yay.

Selçuk, H. (2008). Osmanlı Devletinde Merkez-Taşra İlişkisi Bağlamında Avarız, Nüzul ve Sürsat Vergileri (Şer'iyye Sicillerine Göre XVII. Yüzyılda Kayseri Sancağı). Erciyes Üniversitesi Sosyal Bilimler Enstitüsü Dergisi, 1 (24), 159-202.

Sevinç, T. (2010). 1695 Sakız Seferi'nde Organizasyon ve Lojistik. Süleyman Demirel Üniversitesi Fen-Edebiyat Fakültesi Sosyal Bilimler Dergisi, 2010 (21), 59-79.

Tatar, Ö. (2005). XVIII. Yüzyılın İlk Yarısında Çukurova'da Aşiretlerin Eşkıyalık Olayları ve Aşiret İskânı (1691-1750). [Yayımlanmamış Doktora Tezi]. Frrat Üniversitesi.

Toprak, S. V. (2015). Besni 1846 Tarihli Bir Kefalet Defterine Göre Nüfus ve Sosyal Hayat. Adıyaman Üniversitesi Yay.

Türkmen, M. N. (2002). Kamaniçe Seferinin Lojistik Hazırlıkları. [Yayımlanmamış Doktora Tezi]. Ankara Üniversitesi.

Uluçay, M. Ç. (1944). XVII. Asırda Saruhan'da Eşkıyalık ve Halk Hareketleri. C. H. P. Manisa Halkevi Yay. 